\title{
Land use and land cover dynamics in Leiria City: relation between peri-urbanization processes and hydro-geomorphologic disasters
}

\section{José Leandro Barros ${ }^{1}$ (D) Alexandre Oliveira Tavares ${ }^{2} \cdot$ Pedro Pinto Santos $^{3}$}

Received: 17 April 2020 / Accepted: 21 December 2020 / Published online: 8 January 2021

(C) The Author(s) 2021

\begin{abstract}
The objective of the present study is to evaluate the relation between the spatial and temporal dynamics of Land Use and Land Cover (LULC) and the hydro-geomorphological processes and their impacts. The study area is the city of Leiria, in central Portugal, within the period 1958-2018 based on the historical record of floods and landslides disasters. The LULC analysis shows an accentuated increase in the artificial areas and a continuous decrease in the agricultural areas. With regard to hydro-geomorphologic disaster occurrences, a total of 124 occurrences were identified, having caused a set of impacts. The obtained results allow one to characterize the artificialization process, its intensity and territorial dispersion, as a consequence of urban sprawl and peri-urbanization, along with its consequences in exposure to hydro-geomorphological processes. The analysis concludes that changing the risk drivers resulted in an increase in frequency and spatial dispersion of hydro-geomorphologic disasters over the analysed period.
\end{abstract}

Keywords Land use change $\cdot$ Peri-urbanization $\cdot$ Urban sprawl $\cdot$ Floods $\cdot$ Landslides

José Leandro Barros

leandrobarros@ces.uc.pt

Alexandre Oliveira Tavares

atavares@ci.uc.pt

Pedro Pinto Santos

pmpsantos@campus.ul.pt

1 Centre for Social Studies, University of Coimbra, Colégio de S. Jerónimo, Apartado 3087, 3000-995 Coimbra, Portugal

2 Centre for Social Studies, Department of Earth Sciences, Faculty of Sciences and Technology, University of Coimbra, Rua Sílvio Lima, Pólo II, 3030-790 Coimbra, Portugal

3 Centre for Geographical Studies, IGOT, University of Lisboa, Rua Branca Edmée Marques, Cidade Universitária, 1600-276 Lisbon, Portugal 


\section{Introduction}

The world's population is increasingly concentrating in densely urbanized areas in detriment of rural settlements (UN 2017). According to the same source, (UN 2017), 55\% of the world's population lives in urban areas, when this value in 1950 was only $30 \%$, with projections pointing to $68 \%$ in 2050 . If we analyze the European urban population in 2017, the percentage is 74 and $65 \%$ for Portugal (UN 2017). The increasing concentration of population and economic activities in urban areas gives rise to the need for expansion towards their peripheral areas. In this way there is a landscape change, which translates into a progressive fragmentation of the territory leading to a growing miscellany of uses and occupations (Gaspar 2005), turning the process of identifying the boundaries between urban and rural increasingly complex (Salgueiro 2006).

There are several factors that promote a constant territorial mutation giving rise to the dynamics of LULC that can be grouped into the demographic, social, economic, biophysical, cultural or environmental domains (Lambin and Geist 2008; Sherestha et al. 2011; Tavares et al. 2012; Li et al. 2013). Thus, there is a constant and intense process of alteration and reorganization of the peripheral spaces that originate new processes of LULC resulting in intense processes of peri-urbanization (Rojas 2002; Duràn 2006; Barros et al. 2018). This occurs transversally at the European level where there is an annual growth four times higher for the peri-urban areas compared with urban areas (Piorr 2011; Nilsson et al. 2013; Fertner et al. 2016). In this process of expansion, there is often a rapid and less controlled growth of the artificialized areas giving rise to urban sprawl processes that the European Environment Agency calls "unplanned incremental urban development, characterized by a low density of land uses on the urban fringe" (EEA 2006; see also Piorr 2011; Nijkamp and Perrels 2018). In this study, peri-urbanization is understood as the process of the physical expansion of cities, but also of the dissemination of social, economic and cultural patterns inherent to the urban phenomenon (Duràn 2006).

In Portugal, the growing dynamics of urban expansion in the mid-twentieth century, dominated by a legal system associated with fiscal, land and housing policies (Cavaco et al. 2015) has led to an excessive, and in most cases, unplanned soil artificialization, giving origin to fragmentation and territorial dispersion. Therefore, often provoking diseconomies in the national urban system (INE 2004; Cavaco et al. 2015). In the present study, the artificial areas are understood according to the definition given by the Portuguese Territory's General Directorate (DGT 2019, p. 20) that they are areas intended for human intervention activities, which include built fabric areas, industrial and commercial areas, areas dedicated to tourism, infrastructures, road and rail network, service areas, gardens and equipment. The soil artificialization is understood, as the process of change from an agricultural, forest or another natural area towards artificial areas.

The continuous spatial process of urban expansion, which is the origin of peri-urban areas, is often related to urban sprawl processes that dispel the boundaries between rural and urban (Piorr 2011; Hennig et al. 2015; Masini et al. 2019). This process of transformation is characterized by a set of changes, namely in terms of land use changes, land use competition, demographics, social, economic and environmental changes, thus resulting in urbanization of previously rural territory (Schneidewind 2006; Freire et al. 2009; Meneses et al. 2018). However, most of the time the process of LULC linked to urban expansion is carried out without taking into account the different physical conditions of the territory and a comprehensive knowledge of the various intrinsic dynamics of the natural environment. In this sense, the interplay of the occupation of the territory with its natural dynamics 
originates many of the risk-inducing processes that lead to disasters (Pedrosa 2006; Pattison and Lane 2012; Chadchan and Shankar 2012; Buhaug and Urdal 2013; Sofia et al. 2017).

The increasing artificialization of the soil and the resulting changes, such as the alteration and destruction of the vegetation cover, alteration of slopes and the soil sealing will have a decisive influence on the surface and underground runoff. This fact coupled with the prediction that extreme hydrological events will become more frequent and damaging due to global warming (Beniston et al. 2007; Trenberth 2011; Field et al. 2012) would lead to more frequent occurrences of disaster events of hydro-geomorphologic origin. However, there is a great spatial and temporal variability related to these processes. There is still a great degree of difficulty in determining and predicting the interactions between global warming, anthropogenic influence and occurrences of hydro-geomorphologic disasters. Although according Seneviratne et al. (2012, p. 114) "There is high confidence that changes in heatwaves, glacial retreat, and/or permafrost degradation will affect slope instabilities in high mountains, and medium confidence that temperature-related changes will influence bedrock stability. There is also high confidence that changes in heavy precipitation will affect landslides in some regions". Regarding floods, the same author argues that changes in flood magnitude and frequency can be expected in regions where temperature changes affect the type of precipitation. Seneviratne et al. (2012, p. 113) claim that: "There is medium confidence based on the projected increases in heavy rainfall that would contribute to increases in rain-generated local flooding, in some catchments or regions".

In recent years, some studies have analysed the relationship between the occurrence of LULC and landslides (Glade 2003; Alcántara-Ayala et al. 2006; Papathoma-Köhle and Glade 2013; Reichenbach et al. 2014; Persichillo et al. 2017; Guerra et al. 2017; Gariano et al. 2018; Vitagliano et al. 2020) and floods (Li et al. 2009; Onishi et al. 2014; Carisi et al. 2016; Zhang et al. 2018) some of them addressing linkages to climate change. With regard to landslides, several studies point to the importance of LULC of anthropic origin in slope instability, leading to the activation or reactivation of landslides (Meusburger and Alewell 2008; Van den Eeckhaut et al. 2009; Ravetz et al. 2013; Bruschi et al. 2013; Reichenbach et al. 2014). Some authors even argue that land use change may be more detrimental to future landslides than climate change (Crozier 2010; Anderson and Holcombe 2013).

The principal objective of this work is the evaluation and comparison with the spatial and temporal trends of LULC between 1958 and 2018 for the city of Leiria, and its relation to episodes of hydro-geomorphologic occurrences. The research questions are the following: what are the changes in the land use for the period 1958-2018? What are the principal spatial and temporal trajectories related with land use classes? What are the principal dynamics over time in the city centre and its surroundings? What is the spatial and temporal distribution of hydro-geomorphologic occurrences like floods and landslides in the study area? What is the relation between land use dynamics and these occurrences? What are the main impacts of the floods and landslides in the study area? How can we design a more resistant urban fringe?

The city of Leiria was chosen for the present study due to the fact that it is a mediumsized city, with a marked dynamic of LULC in the last decades, with an intense population growth since the 70's. On the other hand, it also presents a consolidated history record of occurrences of hydro-geomorphologic origin, namely floods and landslides. The study area can be representative of the medium-sized cities in Europe which are poles of attraction for the rural population due to employment-based social dynamics, but maintaining close spatial relationships with agroforestry use and riverside environmental protection areas. 


\section{Study area}

The study area is a part of the city and municipality of Leiria, located in the Central Region of mainland Portugal. It is centred on the City Council and has a circular shape with a $4 \mathrm{~km}$ radius and an area of $50.26 \mathrm{~km}^{2}$ (Fig. 1), including the urban core and peripheral areas, with a total of 63,399 inhabitants (INE 2012).

In terms of geology and morphology, the study area is located to the north of the Limestone Massif of Estremadura in a large sedimentation area called Lusitanian Basin, which in the Mesozoic settled in the tectonic trench limited by the Hesperian Massif and Western Continent (Veiga 2011). With regard to tectonics, the study area falls within the area of the Monte Real and Leiria diapires (Teixeira and Zbyszewski 1968). The region is characterized by its diversity of geological units, with ages between the Jurassic and Quaternary, where two groups of lithological formations are distinguished: formations of magmatic and sedimentary origin. The sedimentary formations correspond to alluvial deposits, fluvial terraces and Pliocene sandstones and clays/silts. The surrounding hills present Jurassic marl material sequences and formations of magmatic origin corresponding to predominant dolerite domes and veins (Teixeira and Zbyszewski 1968; Veiga 2011). The altitude ranges from approximately $7-440 \mathrm{~m}$.

The lower zones correspond to the alluvial plains of the Lis and Lena rivers, which intersect the typhoon valley Parceiros-Leiria. Regarding the hydrological setting, Leiria city is located in the hydrographic basin of the Lis river, which is also crossed by its tributary Lena (Fig. 1). In the study area, the Lis presents an open valley on a densely populated plain, with emphasis on the man-made changes in the river course made in the past. This change was carried out with the objective of controlling floods, diverting the river from the

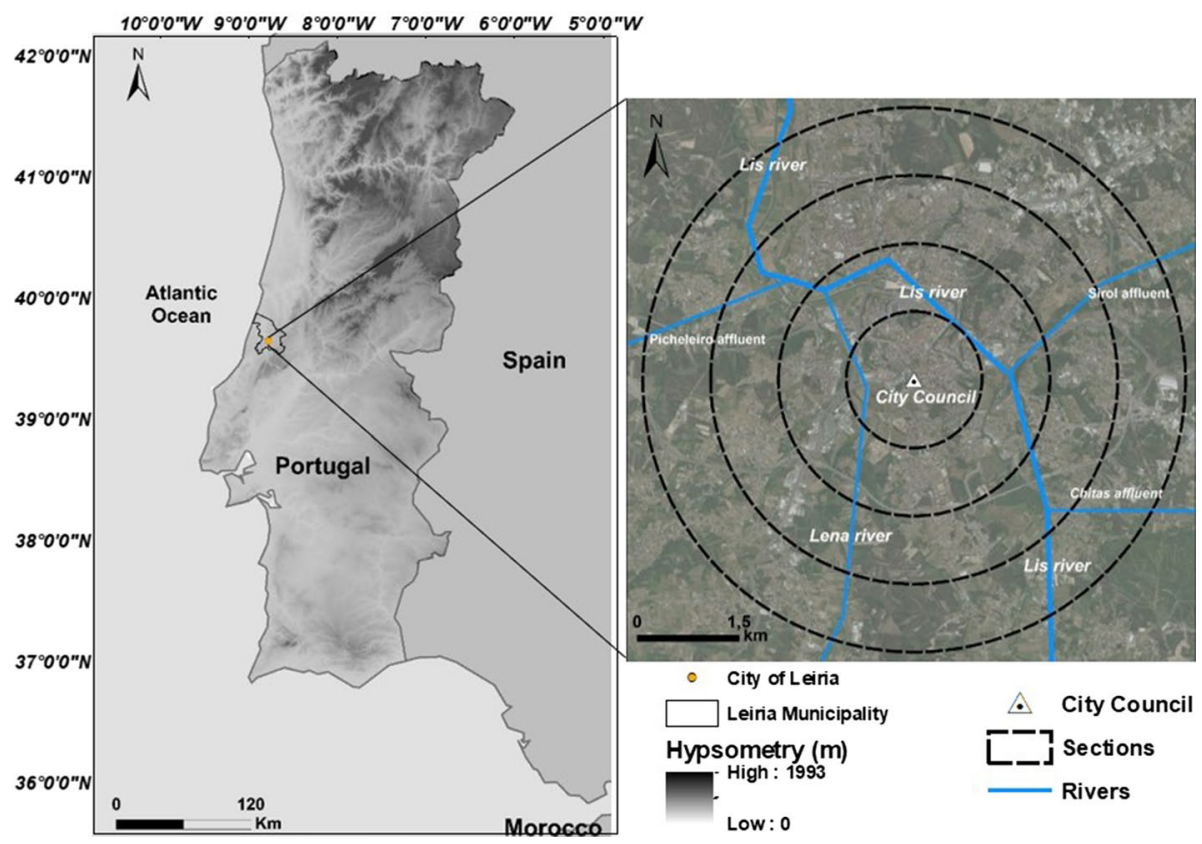

Fig. 1 Location of the study area 
city. However, currently, due to the process of urban expansion and peri-urbanization, the river has returned to occupy a central place in the study area (Veiga 2011; Pinhal 2016). In relation to the Lena, its floodplain is essentially occupied by agricultural and some artificial areas that include housing, road network and warehouses. The Lis river and its tributaries present a torrential pluvial character, registering a great variability in quantitative annual flows. According to Jacinto (2009), this fact affects the level of the aquifers and groundwater level, often giving rise to risk situations associated with floods and landslides. In the study area, there are historical records of flooding associated with human and material losses.

The pluviometric regime of the study area is characterized by great variability, with the highest concentration (75\%) occurring in the winter months between October and March. According to data from the Leiria weather station, between the hydrological years of 1930/1931 and 2016/2017, the precipitation values varied between $446.7 \mathrm{~mm}$, verified in $2004 / 2005$, and $1805.6 \mathrm{~mm}$, verified in 1940/1941. The average annual rainfall is $879 \mathrm{~mm}$, with January being the wettest month, with an average of $129.7 \mathrm{~mm}$.

\section{Methodology}

\subsection{Land use and land change}

The present work intends to analyze the Land Use Land Cover (LULC) between 1958 and 2018 and its relation with the documented hydro-geomorphologic occurrences. The analysis of LULC was carried out with recourse to a set of four photographic mosaics dated from 1958, 1985, 1995 and 2018. The images were analysed and processed according to the procedures presented by Tavares et al. (2012) and Monteiro and Tavares (2015). The adjustment of the different imagery scales was performed according to Monteiro and Tavares (2015), and the integration of images from different sources was complemented by fieldwork, checked by a supervised analysis of the urban fabric, the complex and mixed uses and the land occupation with degraded characteristics.

A classification system was established according to Bossard et al. (2000), based on the Corine Land Cover (CLC) classification defined by the European Environment Agency (EEA 1990). In the next phase, a geographic information system was developed for the classification of polygons of land use, applying the previously defined classes (Skokanová et al. 2012; Tavares et al. 2012; Monteiro and Tavares 2015). For the study area, a base of 24 disaggregated classes was initially identified. In a sequent process these 24 classes were reclassified and aggregated into six major classes, namely: artificial areas, agricultural areas, forest areas, shrub vegetation areas, sparsely vegetated areas and inland waters, using the performance analyses according to Barros et al. (2018).

The analysis of the dynamics of land use for the study area was implemented using a map to map resemblance, involving a set of successive images, with cross-references to define the dynamics of LULC. From this act a set of matrices were created and carried out for the six aggregated classes, for the periods 1958-1985, 1985-1995, 1995-2018 and 1958-2018. The analysis of the dynamics of LULC between 1958 and 2018 was also complemented by the use of two different indicators, also applied in previous studies (Long et al. 2007; Tavares et al. 2014; Barros et al. 2018): the annual rate of artificialization of surfaces (AS) and the stability grade (SG) (Table 1). The AS is an indicator that assesses the dynamics of urbanization in different periods in a certain area. The SG expresses the 


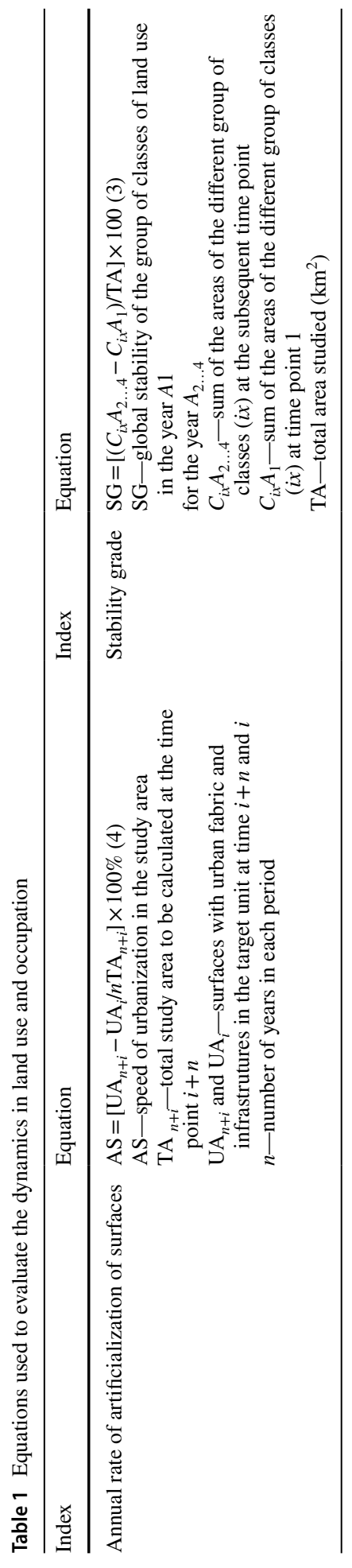


proportion of the landscape that had not experienced a transition to any different category of land use (Tavares et al. 2012).

For the propose of the analysis, the study area was divided into four sections, as performed by others authors (Loibl and Toetzer 2003; Gallent et al. 2006: Leontidou and Couch 2007; Freire et al. 2009; Ravetz et al. 2013) with the aim of understanding the different dynamics and processes of LULC in the central urban core and in the peripheral areas. These different studies show that the greatest transformative force is emerging from a centre, representative of political or economic power. In this study, the different sections are considered according the EU PLUREL project (Piorr 2011; Ravetz et al. 2013). In this sense, Sect. 1 corresponds to the city centre that includes the Central Business District and many civic and cultural functions. Section 2 to the inner urban area, that stands out, with a higher built density that includes residential, commercial and industrial types. Section 3 to a suburban area with lower density, but contiguous built-up areas with local commerce and services and Sect. 4 to the urban fringe periphery area. According Piorr (2011) and Ravetz et al. (2013), the area corresponding to Sects. 1, 2 and 3 is called a "Built Up Area". The junction of Sect. 4 to the other sections is designated by Functional Urban Area (FUA).

\subsection{Hydro-geomorphologic history records}

In the present study, the history occurrences of hydro-geomorphologic origin, namely natural processes of hydrologic (floods, flash floods) or geomorphologic (landslides) nature will be considered. The survey of the occurrences for the study area was conducted within the framework of the DISASTER project (Zêzere et al. 2014). The database that resulted from the project consists in a collection based on hemerographic sources published daily or weekly between 1865 and 2018 (17 newspapers of national or regional circulation previously characterized by Zêzere et al. 2014). A total of five newspapers were surveyed for some specific dates in order to complete or validate some occurrences. In total, 145,344, newspapers were surveyed in order to identify hydro-geomorphologic occurrences. According Zêzere et al. (2014) all occurrences were validated using the newspaper for the main report and cross-checking different news sources (national, regional and local newspapers). Statistical tests have shown that the DISASTER database can be considered complete by records gathered since 1936 (Zêzere et al. 2014). For the present study, only the occurrences identified between 1958 and 2018 were considered. For the systematization, a database was elaborated, later exported to Excel (Microsoft Office ${ }^{\circledR}$ ), which contained fields of analysis regarding: (1) date and site of occurrence of the event; (2) source of information and news characteristics; and (3) direct and indirect associated losses and damages.

According to the methodology described by Zêzere et al. (2014), "occurrence" was considered according to the geographically identifiable location affected by an event of hydro-geomorphologic origin for which losses and damages resulting from flooding, and/ or landslides in slopes are reported. The same author defines event as a set of occurrences sharing the same trigger which can have a widespread spatial extension and a certain magnitude. In the present work, all occurrences present detailed information about the time period of the respective occurrence, namely the hour, day, month and year. This fact is important because it allows one to attribute a high degree of accuracy to the information collected, as advocated by Parise and Vennari (2013, 2017). The DISASTER database presents a wide range of information on the occurrence characteristics and damages (Zêzere et al. 2014). The first includes data on flood or landslide subtype, date of occurrence, location and triggering factor. The second includes structural damages (damage to buildings 
and damages to rail and road networks) and social consequences (human damage, gender of fatalities and circumstances surrounding the fatalities). The inclusion of this information allows one to increase the level of detail of the database, allowing a hierarchical organization and a detailed level of multidimensional analysis, going from national to local scale, as is defended by (Napolitano et al. 2018). The georeferencing and analysis of occurrences, the visualization and cartographic production was done in Geographic Information System (ArcGIS 10.5 ESRI ${ }^{\circledR}$ ). The georeferencing of each occurrence was performed according to Zêzere et al. 2014, by adopting the following procedures: (a) location with exact coordinates (1: 1000 scale); (b) location based on toponymy (1:10,000 scale); (c) location in the centroid of the parish; and (d) location in the centroid of the county. In the present study, only occurrences with an exact location were considered. It should be noted that the location of each occurrence is methodologically influenced by the quality of description present in the reported news.

In the present work, the occurrences were grouped into two groups, based on the impacts associated, namely: occurrences with human losses (occurrences that meet the criteria of the DISASTER database, namely any flood or landslide that caused casualties, injuries or missing, evacuated or homeless people) and occurrences with exclusively material losses.

\subsection{Cluster analysis}

A cluster analysis was performed for the evaluation of the relation between the aggregated land use classes and the different impacts. This is an exploratory statistical technique of multivariate analysis that allows grouping variables into homogeneous groups based on their common characteristics (Marôco 2014). In this statistical analysis the objective was to assess the degree of relation between the two typologies of impacts (occurrences with human losses and occurrences with exclusively material losses) and the three more representative aggregated land use classes (artificial areas, agricultural areas and forest areas) between 1958 and 2018. However, in the sense of strengthening the analysis and since the negative consequences inherent to the LULC can take a few years or decades to be reflected in negative impacts, some previous evidence related to floods and landslides has been taken into account. In this analysis, the cases are each a section of $1 \mathrm{~km}$ radius in the 4 time periods, that is, a total of 16 cases. Thus, a hierarchical cluster analysis was performed for the five variables by Ward's method testing a grouping of variables in 2, 3 and 4 clusters and using the phi coefficient as a similarity measure. The procedure was done using SPSS statistics ${ }^{\circledR}$ software.

\section{Results}

\subsection{Land use and land cover change and occupation}

Figure 2 presents the dynamics of the six aggregated classes between 1958 and 2018. Its analysis allows one to conclude the existence of systematic changes in land use that are translated in the increase in artificial areas with a positive variation of $342 \%$ between 1958 and 2018 and a considerable decrease in the agricultural areas, which shows a negative variation of $55 \%$. Also noteworthy is the increase in forest areas, which in the considered period presented a positive variation of $26 \%$. 


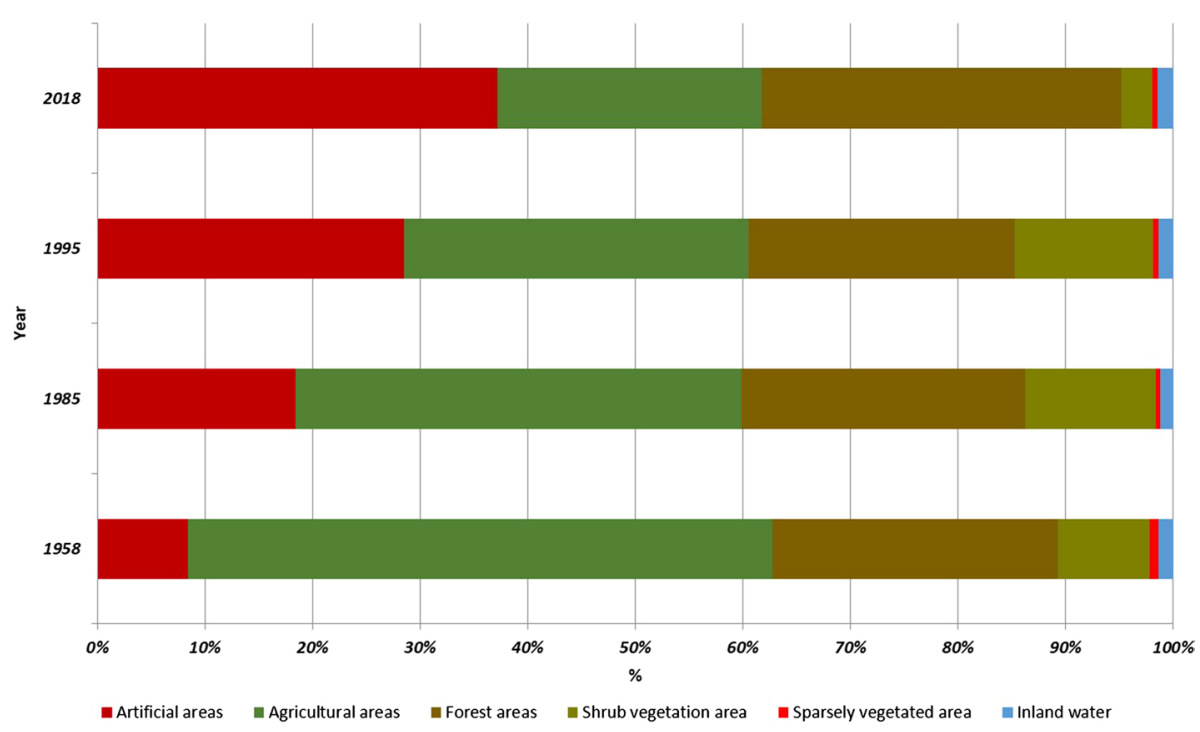

Fig. 2 Classes of land use from 1958 to 2011 for the study area

Figure 3 presents the cartographic representation of the evolution of the six aggregated land use classes for the period 1958-2018. From the outset, it is possible to observe a progressive increase in territorial complexity of uses, as a reflection of peri-urbanization processes. It is possible to verify that in 1958 agricultural areas were predominant (54.3\%), where the artificialized areas $(8.4 \%)$ presented an irregular distribution along the territory, with a clear concentration in the city centre. Furthermore, the importance of forest-related areas was noteworthy, which in 1958 accounted for $26.6 \%$ of the total area of study, with a strong concentration in the most outer urban areas.

The temporal evolution present in Fig. 3 shows a clear modification in the territorial assets related to land use and occupation present between 1958 and 2018. A constant increase in soil artificialization can be noticed with a clear focus on the city centre (Sect. 1) that emerges as the pole dynamizing the landscape of the study area towards the more peripheral areas. The artificialization process was carried out essentially at the expense of the agricultural areas, which in the periods in question presented a decrease of $55 \%$ in terms of area, but also with the use of shrub vegetation areas. The forest areas, have the particularity of presenting a distinct dynamic over the analysed period: interest led to some maintenance works between 1958 and 1995, they show an increase between 1995 and 2018.

As regards the artificial areas, there is a dynamic of expansion from the city centre (Sect. 1) to the periphery, especially for the inner urban area (Sect. 2) and the suburban area (Sect. 3). In 1958, the artificial areas presented a lower percentage than the agricultural and forestry areas, in all sections. However, this reality is changed during the period under analysis, where we see a clear and intense expansion of artificial areas (Fig. 4). On the other hand, we verified a constant retreat of the agricultural and shrub vegetation areas, where it should be noted that the process of artificialization of previously agricultural and shrub vegetation areas decreases from the centre to the periphery. The forest areas were the object of some maintenance between 1958 and 1995 with a considerable growth between 1995 and 2018. This fact is observed through Figs. 3 and 4 where it is possible to mention 

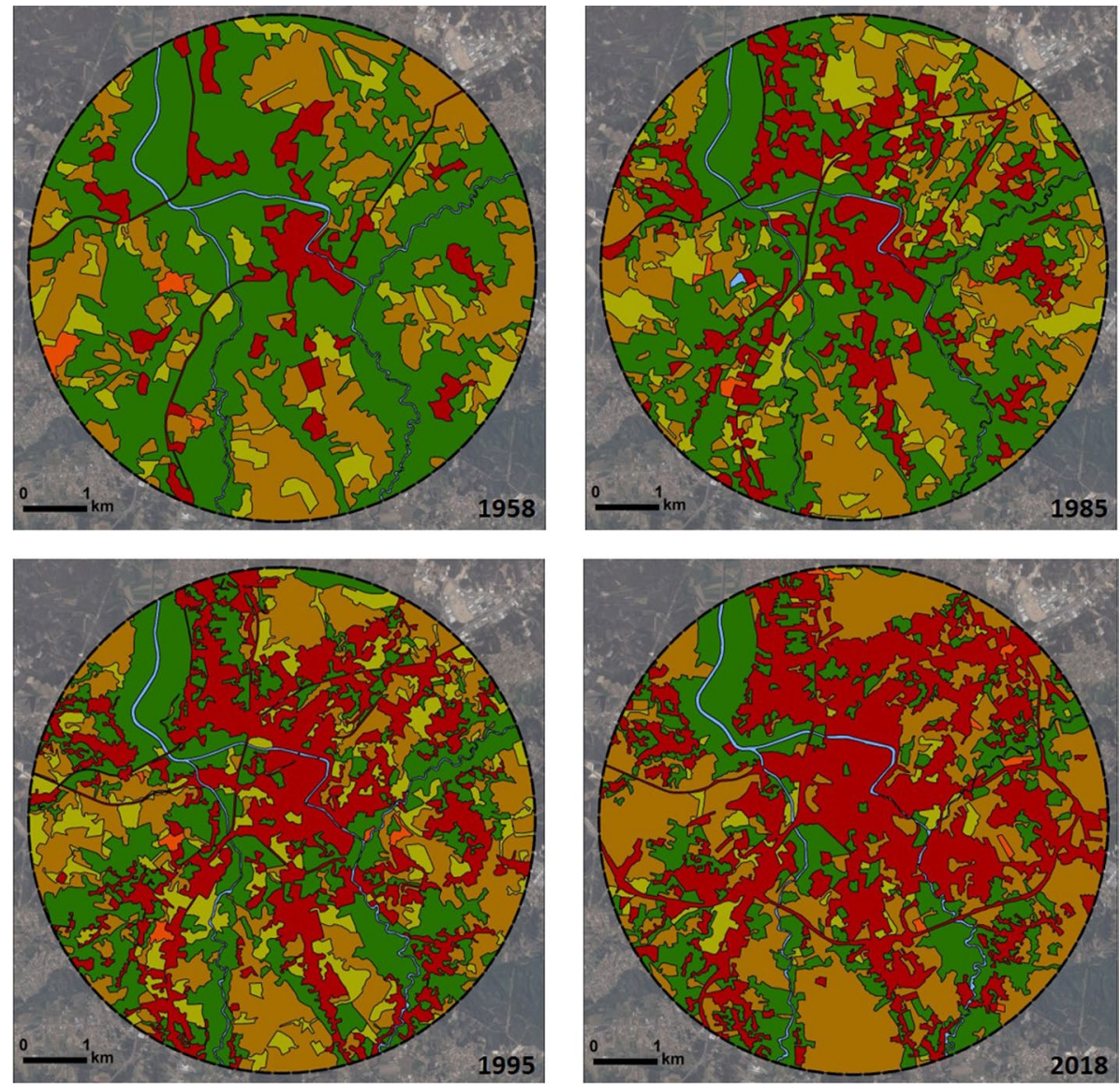

\section{Artificial areas}

Shrub vegetation areas

Agricultural areas

Sparsely vegetated areas
Forest areas

Inland water

Fig. 3 Land use and occupation for the study area based on image classifications by year

that in the most peripheral areas, and despite the fact that considerable soil artificialization is observed, these areas are still marked by a strong presence of forest and agricultural use. However, distinct differences between these two land classes can be observed. While the agricultural areas show a greater retreat in the city centre and inner urban area between 1958 and 2018, the forest areas present some stability in all sections between 1958 and 1995, with the exception of the suburban area (Sect. 3) that presents a greater decrease. However, in the period between 1995 and 2018, the forest areas show a considerable growth in all sections.

Another fact to register relates to the forest areas, which along with the artificial areas, are the only two land use classes that show an increase between 1958 and 2018. This process of growth is related to processes of loss of profitability and importance of the agricultural sector, in economic and employment terms, that result in the abandonment of agricultural land. It is also noteworthy that the gain of these areas is also due to the transformation 

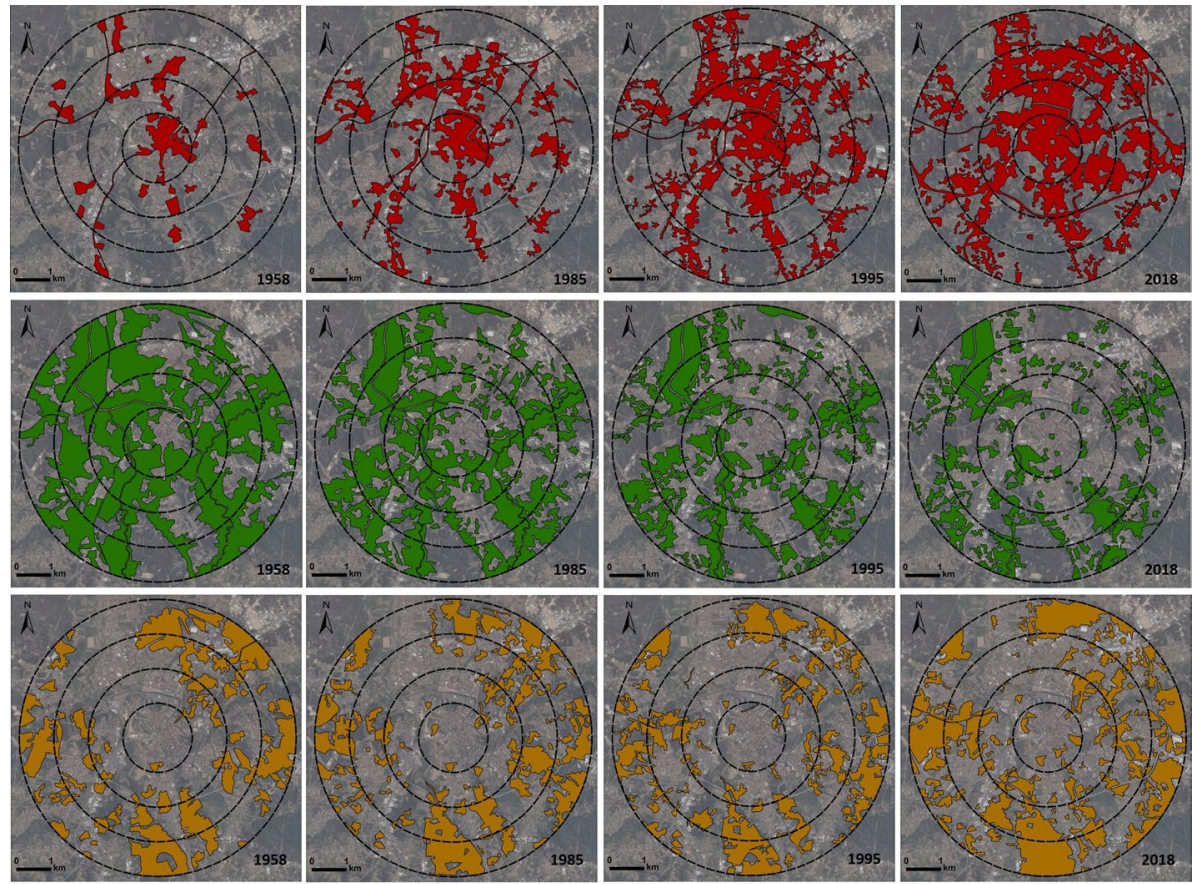

Artificial areas

Agricultural areas

Forest areas

[-] Sections

Fig. 4 Evolution of the three most representative land use classes by year and sections

of shrub vegetation areas into forest and artificial areas. For the evaluation of the dynamics in LULC, the stability grade (SG) and the rate of artificialization (RA), presented in the Fig. 5, were calculated. In terms of SG there is a constant increase between 1958 and 2018. If we consider the entire period under analysis, we find that the average value of the SG is $42.05 \%$, which reflects a relevant transformation process of land use change. In terms of RA, there is a sharp and continuous growth between 1958 and 1994, with an annual growth of $0,19 \%$ between 1958 and 1984 and $0,51 \%$ between 1985 and 1994 . This is a result of the process of urban expansion observed since the 70's linked to the approval of a framework of municipal plans that encouraged the construction of a set of infrastructures. From the mid-1990s onwards, the RA showed a steady and marked decrease until 2018. This can be explained by the approval of territorial planning instruments that limit urban expansion and impose a number of limitations in terms of land management for ecological and agricultural protection areas. These instruments include the approval of a new Master Plan in 1994 and the approval in 1993 of the National Agriculture Reserve (RAN) and in 1996 the National Ecological Reserve (REN).

\subsection{Hydro-geomorphological occurrences}

A total of 124 flood and landslide occurrences were identified, of which eight are related to occurrences with human losses and 116 to occurrences with exclusively material losses. It should also be noted that 110 occurrences refer to floods and only 14 to landslides. 


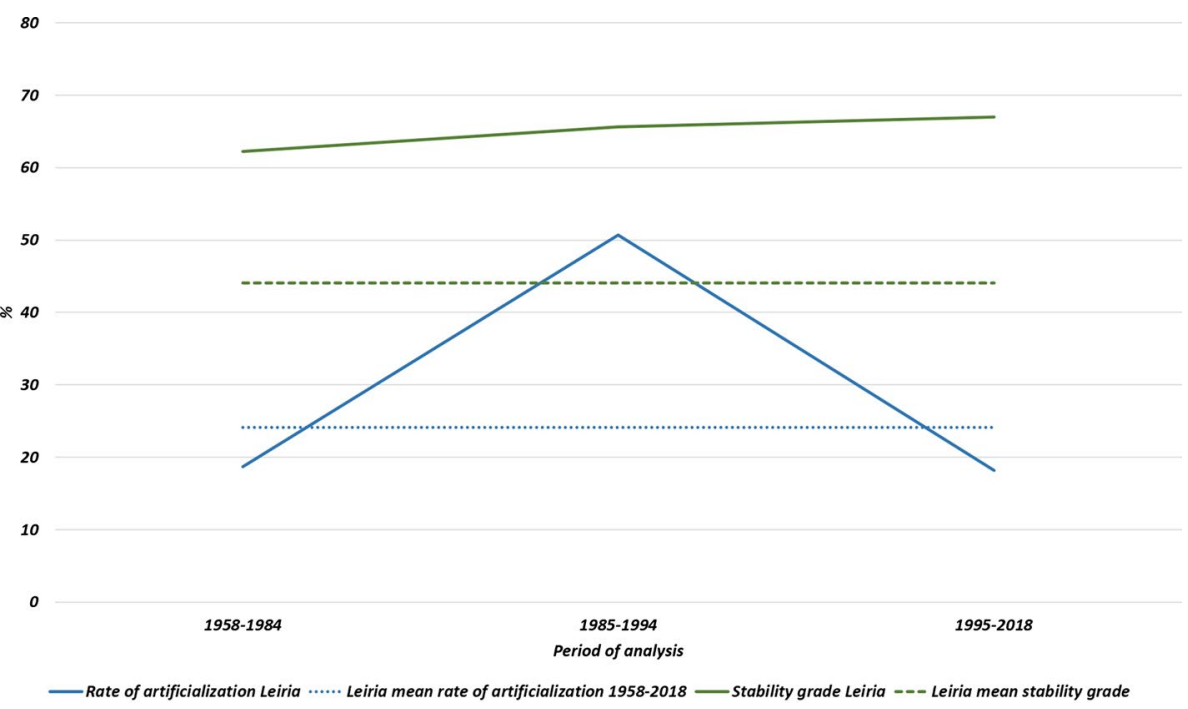

Fig. 5 Parallel between the stability grade (\%) and the rate of artificialization (\%) in the city of Leiria

\subsubsection{Spatial distribution and characterization of occurrences}

The distribution of occurrences of hydro-geomorphologic origin between 1958 and 2018 in the area of study present temporal and spatial variations that must be analysed. The municipality of Leiria and more specifically its urban area, with emphasis on the city centre, presents a consolidated history of hydro-geomorphologic occurrences (with emphasis on floods) with occurrences dating from the beginning of the fifteenth century (Andrada 1982). It should be noted that the occurrences of landslides appear associated with five distinct geological units namely, in descending order of number of occurrences: Jurassic marl and marly limestone; Quaternary deposits; Paleogene detrital rocks; Cretaceous limestone and Pliocene detrital rocks. With regard to floods, occurrences arise associated with contexts related to the overflowing of the banks of the Lis river and its tributary Lena. We also highlight the occurrences that correspond to urbanized areas, over floodplain and alluvial areas.

Table 2 shows the different typologies and subtypes associated with the processes that originated the total of 124 identified occurrences, as well as their temporal differentiation. It can be seen that, in relation to floods, flash floods predominate $(73.6 \%)$, this trend being transversal to all analysed periods. The growth of flash floods between 1995 and 2018 stands out, representing $66.6 \%$ of the total occurrences of this subtype and $49 \%$ of the total recorded floods. With regard to landslides, there is a predominance of processes related to rockfalls, followed by debris flows. However, it is necessary to highlight different temporal trends regarding landslide occurrences. For the period 1958-1984 there is only the occurrence of landslides related to rockfalls, 1985-1994 is marked by the absence of landslides. Between 1995 and 2018, there is an increase in the number of occurrences related to landslide, namely related to rockfall and debris flow. There is also an occurrence related to a process of shallow translational landslide.

Table 3 shows the distribution of the two typologies of occurrences considered, distributed over the three periods that resulted from the analysis made for the LULC. From the 
Table 2 Typology and subtypes of the occurrences

\begin{tabular}{llcrr}
\hline Typology & Subtype & Total values & & \\
\cline { 3 - 5 } & & $1958-1984$ & $1985-1994$ & $1995-2018$ \\
\hline \multirow{2}{*}{ Floods } & Progressive flood & 6 & 0 & 5 \\
& Flash flood & 12 & 15 & 54 \\
& Not identified & 12 & 1 & 5 \\
Landslides & Shallow translational slides & 0 & 0 & 1 \\
& Rockfall & 2 & 0 & 6 \\
& Debris flow & 0 & 0 & 5 \\
\hline
\end{tabular}

Table 3 Number and typology of occurrences in the three analysed periods

\begin{tabular}{|c|c|c|c|c|c|c|}
\hline & \multicolumn{3}{|l|}{ Total values } & \multicolumn{3}{|c|}{$\begin{array}{l}\text { Racio values (no. ocurrences/no. } \\
\text { years) }\end{array}$} \\
\hline & 1958-1984 & 1985-1994 & $1995-2018$ & 1958-1984 & 1985-1994 & 1995-2018 \\
\hline $\begin{array}{l}\text { Occurrences with human } \\
\text { losses }\end{array}$ & 3 & 1 & 4 & 0.1 & 0.1 & 0.2 \\
\hline $\begin{array}{l}\text { Occurrences with exclu- } \\
\text { sively material losses }\end{array}$ & 29 & 15 & 72 & 1.1 & 1.5 & 3 \\
\hline
\end{tabular}

outset, it is possible to observe that the period 1995-2018 is that during which the major number of occurrences with human and exclusively material losses was recorded.

However, due to the temporal differences between the three periods considered, it was necessary to find a way to standardize the number of occurrences by the different periods. Thus, a ratio was used, which consisted in dividing the number of occurrences by the number of years of each period. The analysis of the obtained ratios shows that the period 1995-2018 has the highest ratios in the two typologies of occurrences observed, confirming the trend of total values. However, the period 1985-1994 stands out with the second highest ratio relative to occurrences with exclusively material losses.

In terms of the spatial distribution of occurrences, Fig. 6 shows its territorial distribution over the three periods under analysis and for the entire period between 1958 and 2018. Figure 6 also shows the relationship between the impacts and typologies of the different occurrences with the evolution of the urban limits of Leiria over the last seven decades that resulted from the application of a set of planning frameworks (Barros et al. 2018). It is still possible to correlate the different occurrences with the areas threatened by the risk of floods and erosion in REN, in application since 2016. Each section is centred on the City Council and has, respectively, 1, 2, 3 and $4 \mathrm{~km}$ radius. Firstly, it can be observed that in the first and second analysed periods, the occurrences are concentrated in the city centre (Sect. 1) coinciding with the historical centre. However, it should be noted that occurrences with human losses happen in peripheral areas, namely in the suburban area (Sect. 3) in predominantly rural areas of the Lena river, dominated by agricultural and forest areas, for the period 1958-1984. In relation to the period 1985-1994, the only occurrence with human losses is located in the inner urban area (Sect. 2) with increasing dynamics of soil artificialization in a particularly critical area named Ponte das Mestras, with a strong historical record of flood impacts. Regarding the typology and subtypes of the processes at the origin 
Fig. 6 Distribution of occurrences by type of loss and subtype of associated process in the analysed periods
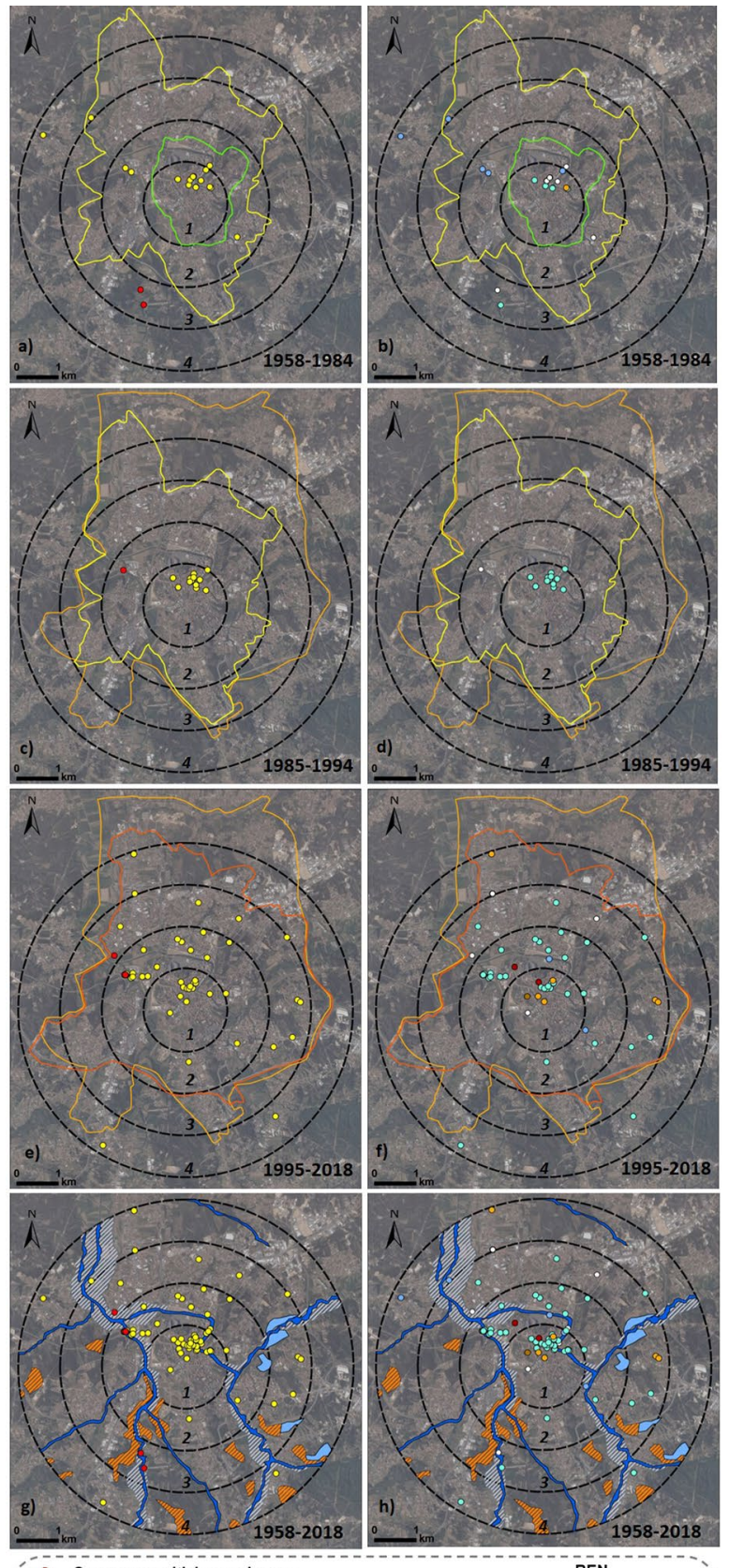

- Ocurrences with human losses

\section{REN}

20 Areas threatened by floods

- Ocurrences with exclusively material losses

Areas threatened by flo
Wareas at risk of erosion

Q Study area

River beds

$\square$ Areas of maxi

1947

- Flash flood

- Rockfall

-1947
-1972

- Progressive flood

Not identified

- Shallow translational slide 
of the occurrences, in the period 1958-1984 flash floods appear almost exclusively in the city centre (Fig. 6b), in impermeable areas, where runoff predominates and where, mainly in episodes of intense precipitation in a short space of time, causes the overload of the rain drainage systems. In this period, there also appear in the city centre, the only occurrences of landslides, related to slopes adjacent to the road network. With regard to progressive floods, these arise in areas adjacent to the River Lis and Lena affecting artificial areas in Sects. 1 and 2 and agricultural areas in Sects. 3 and 4. In the period 1985-1994 (Fig. 6d), there are occurrences exclusively related to flash floods in a context identical to that observed in the previous period.

The analysis of the period 1995-2018 presented in Fig. 6 shows a different distribution in relation to the previous periods, namely with regard to occurrences with exclusively material losses. It should be noted that there is a greater dispersion of this typology of occurrences throughout the study territory, especially in inner urban area (Sect. 2) and in the suburban area (Sect. 3). It is noteworthy that Sects. 1 and 2 present the highest number of occurrences (Table 4), which means a change in trend over previous periods. It is also important to point out the emergence of occurrences in the suburban area (Sect. 3) in the 1995-2018 period, when in the previous periods there is no history of any occurrence with exclusively material losses in this section. In terms of occurrences with human damages, the trend remains the same as in previous periods, that is, its location in peripheral areas to the city centre of Leiria, in peri-urban areas, often in places with a history of occurrences, the Ponte das Mestras area standing out in this particular.

For the 1995-2018 period, there is a predominance of occurrences originating from flash floods, evidencing their dispersion throughout the territory, associated with urban expansion and peri-urbanization processes, as suggested by Barros et al. (2018). Progressive floods appear in the inner urban area in floodbed areas, in areas targeted by an urban requalification process called POLIS Leiria. Regarding landslides, there are occurrences in all sections with the exception of the suburban area (Sect. 3). All occurrences arise in contexts related to slopes adjacent to residential areas and road network, where in some cases results have been caused by inappropriate human interventions. The greatest concentration appears, however, in Sect. 1, where we verified the occurrence of landslides of different subtypes. Virtually all occurrences occur within the urban perimeter, where it should be noted that in 2015, when the Master Plan was updated, there was a contraction of the urban limits (contrary to previous periods) resulting from the inclusion of a set of constraints, some of them arising from REN and RAN, which limit urban expansion (Barros et al. 2018).

Figure $6 \mathrm{~g}$ and $\mathrm{h}$ relates the total occurrences observed in the period 1958-2018 with the constraints related to area threatened by floods and areas at risk of erosion resulting from the REN approved in 2015 for the municipality of Leiria. Although the spatialization of the

Table 4 Number of occurrences by period in the four sections

\begin{tabular}{|c|c|c|c|c|c|c|c|c|c|c|c|c|}
\hline & \multicolumn{12}{|c|}{ Total values } \\
\hline & \multicolumn{4}{|c|}{$1958-1984$} & \multicolumn{4}{|c|}{ 1985-1994 } & \multicolumn{4}{|c|}{ 1995-2018 } \\
\hline & $\mathrm{S} 1$ & $\mathrm{~S} 2$ & S3 & S4 & $\mathrm{S} 1$ & $\mathrm{~S} 2$ & $\mathrm{~S} 3$ & S4 & $\mathrm{S} 1$ & $\mathrm{~S} 2$ & S3 & S4 \\
\hline Occurrences with human losses & - & - & 3 & - & - & 1 & - & - & - & 3 & 1 & - \\
\hline $\begin{array}{l}\text { Occurrences with exclusively } \\
\text { Material losses }\end{array}$ & 23 & 4 & - & 2 & 14 & 1 & - & - & 23 & 25 & 16 & 8 \\
\hline
\end{tabular}


conditions arose in a period after the emergence of the most occurrences, this correlation exercise shows that only $16.3 \%$ of the occurrences of flooding occur in areas identified as being threatened by flooding. It is observed that the majority of occurrences arise in a consolidated urban context, as is the case of the historic centre located in the Sect. 1. However, mainly since 1995 there has been a dispersion of occurrences for areas marked by a recent artificialization related to an industrial relocation to peripheral areas and the emergence of new residential neighbourhoods that accompanies the densification of the road network to the same areas.

\subsubsection{Type of hydro-geormorphologic losses}

Regarding the occurrences with human losses, we verified only eight occurrences for the period under analysis, exclusively associated with floods. Figure 7 shows the impacts associated with this typology of occurrences. One particular note is the number of evacuated people (130) as the main typology of impacts associated with occurrences with human losses, followed by the number of homeless (20) and the existence of casualties (1). The 1995-2018 period has the highest number of impacts, including a total of 56 evacuated and 20 homeless people.

In relation to occurrences with exclusively material losses, Fig. 8 presents the different typologies identified. It should be noted that, in most cases, several typologies of damages may be associated with a single occurrence. The damages associated with road infrastructures and residential and commercial buildings particularly stand out, which represent the great majority (74\%) of the damages associated with this typology of occurrences. In the opposite direction, the residual values of the damages associated with agricultural damages are highlighted.

Figure 9 presents the damages associated with exclusively material occurrences in the three periods under analysis. It is possible to observe that the damages associated with road infrastructures and residential and commercial buildings predominate. Another fact to be

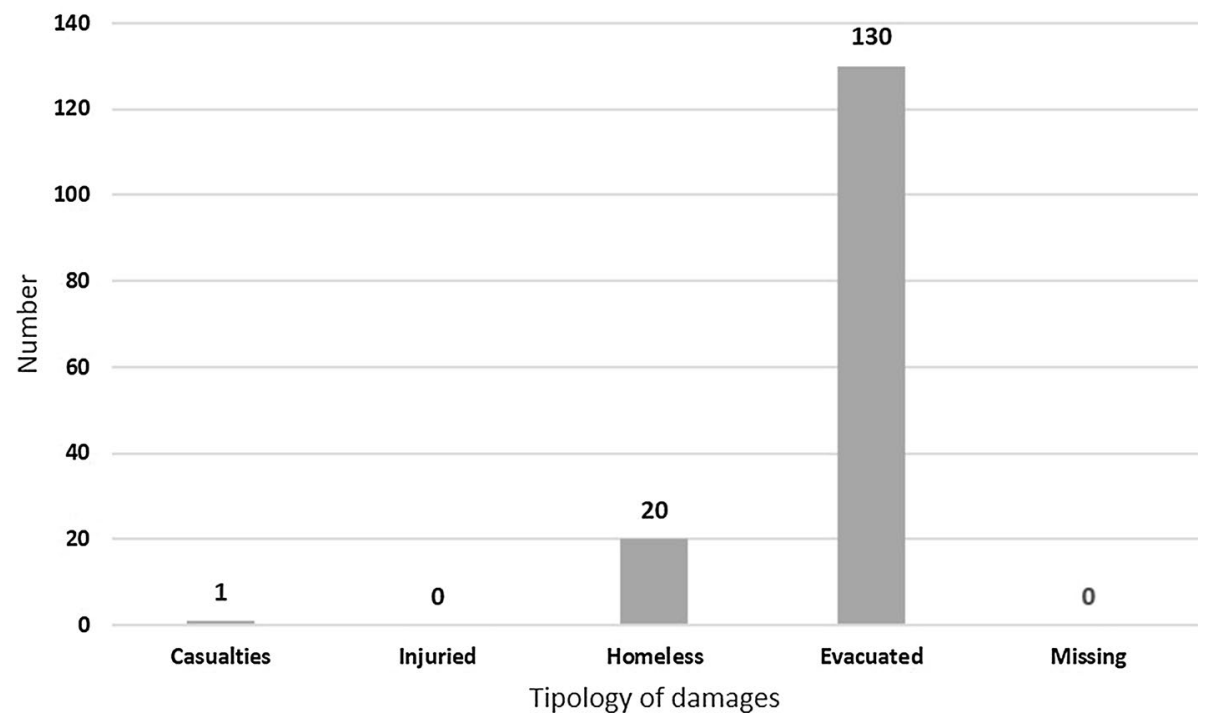

Fig. 7 Typology of impacts associated with occurrences with human losses 


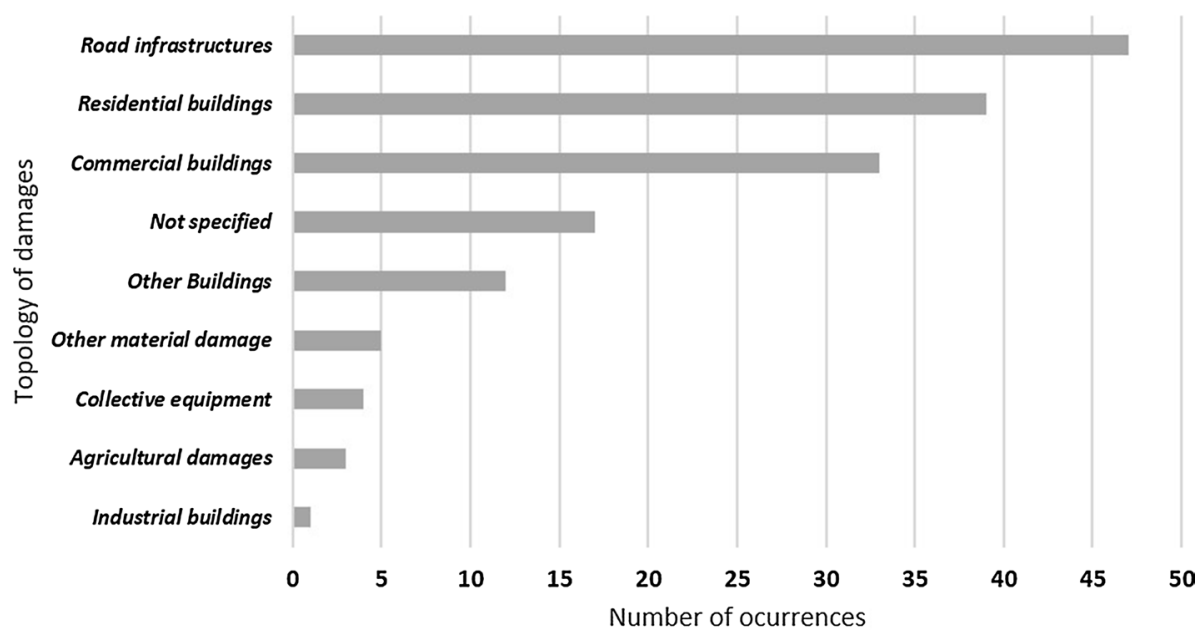

Fig. 8 Typology damages associated with occurrences with exclusively material losses

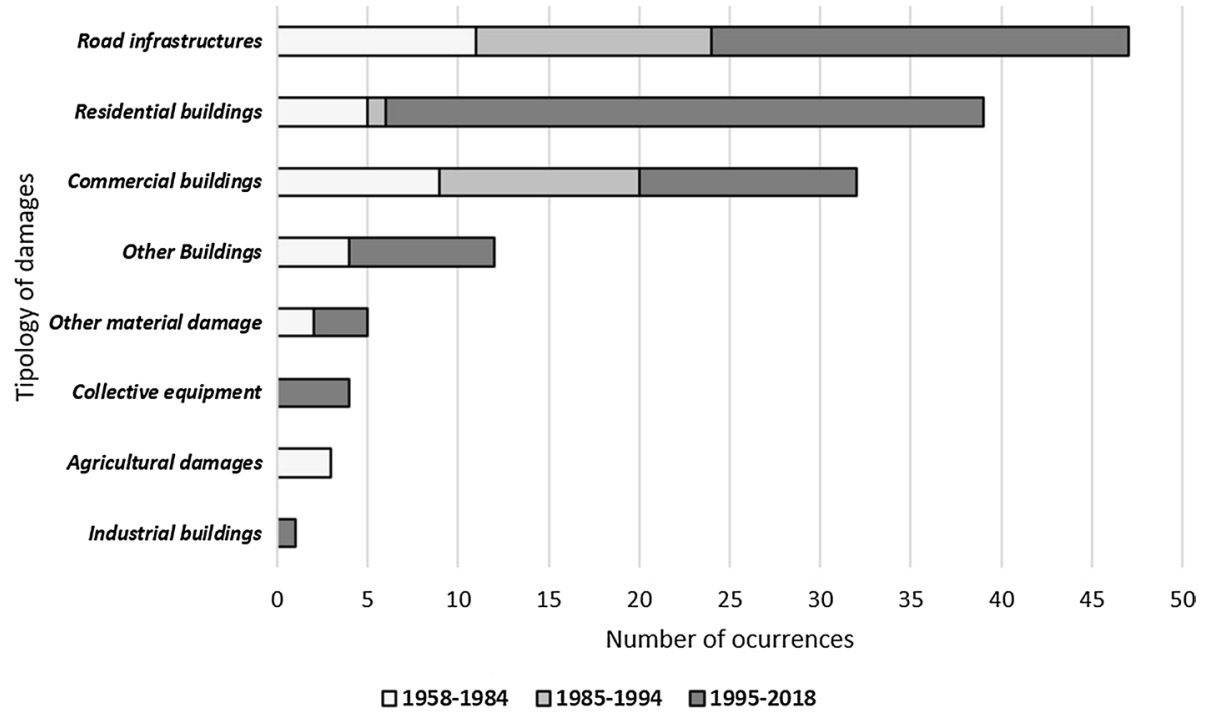

Fig. 9 Typology of damages associated with occurrences with exclusively material losses

noted is that the damages related to residential buildings show a marked growth between 1995 and 2018, becoming the typology of damages with the most occurrences for that period. Another relevant fact is related to the occurrences associated with agricultural damages that present a residual value (three occurrences), occurring only in the period between 1958 and 1984. Finally, it should be noted that in the period between 1995 and 2018 two new typologies of damages that did not have any history of occurrences in previous periods: damages related to collective equipment (floods in schools, cinema, nursing home and in a youth hostel) and related with industrial buildings. 


\section{Discussion}

\subsection{Drivers of land use and land cover change}

The analysis and evaluation of the LULC dynamics at the city of Leiria, in the period 1958-2018, generally highlights the continuous and marked growth of the artificial areas in contrast to the continuous decrease of agricultural areas (Fig. 10). It is also verified that the artificialization of the soil is essentially related to the conversion of agricultural, shrub vegetation and forest areas to artificial areas, these results have already been reported by several authors (Jones et al. 2011; Tavares et al. 2012; Bodesmo et al. 2012; Abrantes et al. 2016; Barros et al. 2018). Throughout the period under analysis, the city of Leiria grew as a pole of attraction. Initially the city was characterized by a strong administrative component surrounded by some industrial hubs and vast rural spaces, with emphasis on agriculture and forestry. The progressive loss of importance and profitability related to the activities of the primary sector and the intense population growth verified since the 70's would originate the growing tertiarization of its urban agglomeration and an industrial relocation to its peripheral areas. The analysis of Fig. 10 shows that artificial areas are the unique class that has a continuous and uninterrupted growth in all sections and in the all periods analysed, with a positive variation of $342 \%$ between 1958 and 2018. Another fact was the intense artificialization of Sects. 2, 3 and 4. This trend is related to peri-urbanization processes in the peripheral areas of the city centre (Teixeira et al. 2014; Monteiro and Tavares 2015; Mantas et al. 2016; Barros et al. 2018).

The increase in soil artificialization observed in the study area resulted in alteration of the natural dynamics in terms of the processes of surface runoff and infiltration that contribute to the increase in surface runoff, contributing decisively to the occurrence of urban floods (Miceli et al. 2008; Pattison and Lane 2012; Zhang et al. 2018). On the other hand, the alteration and artificialization of slopes, the increasing of urbanization in risk areas, the abandonment of rural areas and their agricultural and forestry practices, as well as

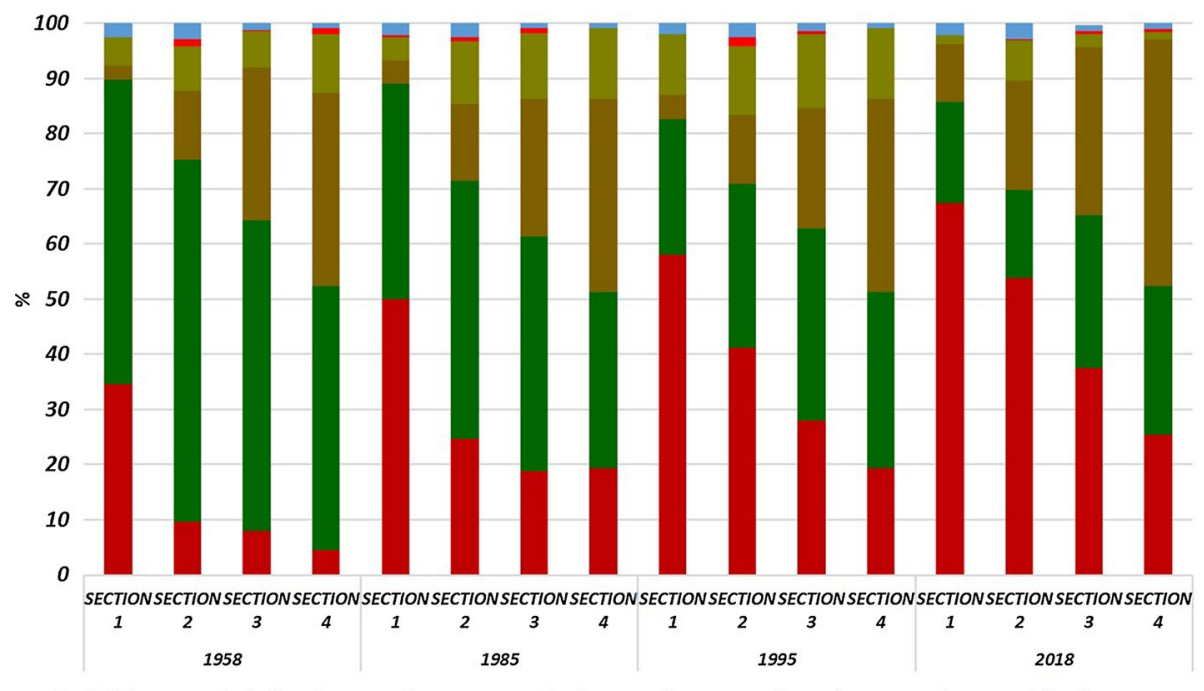

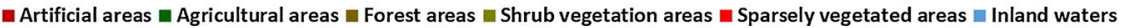

Fig. 10 Evolutions of the aggregated land use classes along the different sections between 1958 and 2018 
deforestation, had a decisive effect on the activation and reactivation of landslides (Glade 2003; Alcántara-Ayala et al. 2006; Persichillo et al. 2017; Pisano et al. 2017). The study area presents a consolidated historical record of occurrences of hydro-geomorphologic origin, namely floods and landslides. The analysis showed a progressive increase in the number of occurrences and associated impacts, with a sharp increase in the period 1995-2018 (Fig. 11).

\subsection{Relation of losses and land use and land cover change}

The analysis of Fig. 11 also shows a spatial variation in terms of number and type of impact of occurrences. It is possible to verify that in the periods 1958-1984 and 1985-1994 the occurrences are concentrated essentially in the consolidated city centre area, namely those with exclusively material losses. However, after the increase in artificialization that occurred until 1994, visible through the RA calculation, there is a pulverization of the occurrences, in the period 1995-2018 (with emphasis on the occurrences with exclusively material losses) for the peri-urban areas, namely in the inner urban area (Sect. 2) and suburban area (Sect. 3). This evolution cannot be dissociated from the peri-urbanization process verified in the study area between 1958 and 2018. With regard to SG, its increase is contrary to the increase in the number of hydro-geomorphological occurrences, concluding that it is the spatial dynamics that determine the occurrences. It should also be noted that the agricultural impacts are underestimated, either due to the successive loss of importance of the agricultural area, or due to the fact that there is a progressive artificialization with the appearance of new residential areas, new road infrastructures and large industrial and commercial areas, affecting the population's mobility and access to functions.

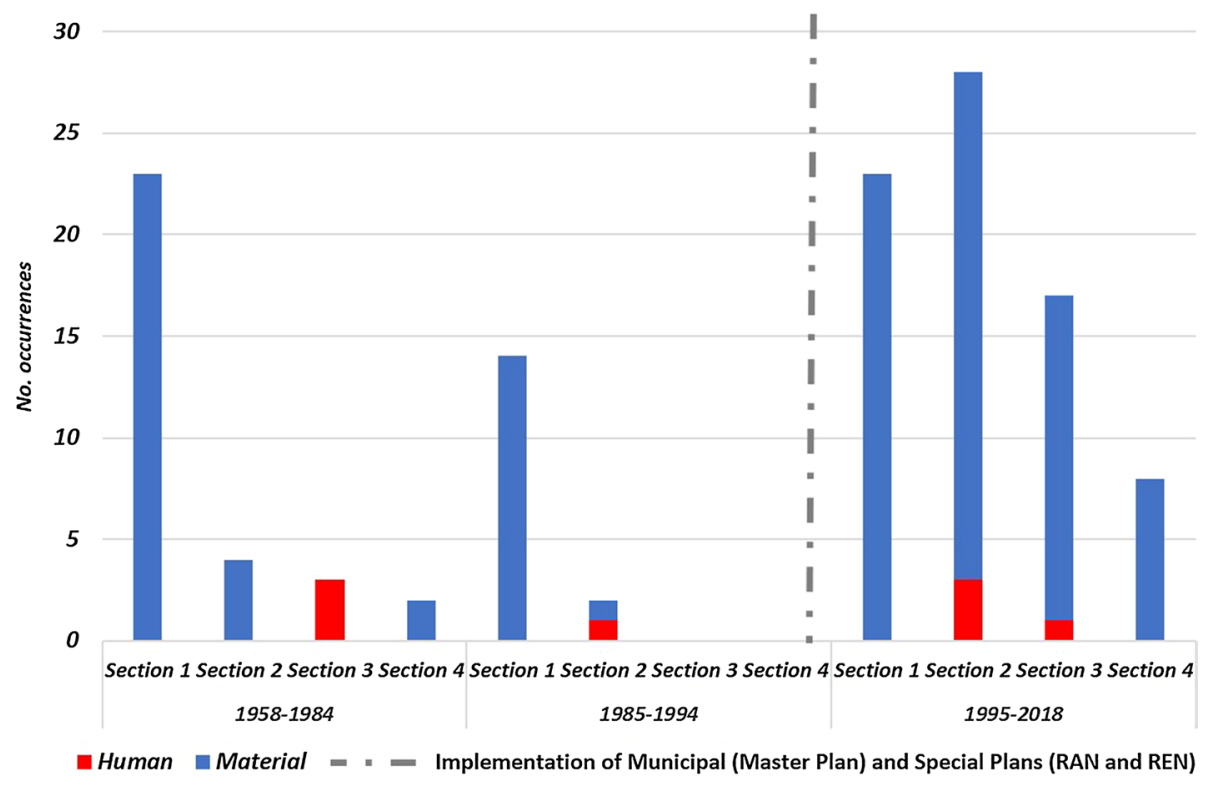

Fig. 11 Evolution of the impacts associated with occurrences of hydro-geomorphologic origin 
It should also be noted that occurrences with human impacts occur only in Sects. 2 and 3, presenting different contexts. For the period 1958-1984 and 1985-1994, occurrences with human losses occur predominantly in rural sections. This pattern is altered in the period 1995-2018 where it is observed that Sects. 2 and 3 are predominantly artificialized. This constant process of alteration of land use and occupation results from a set of geographical forcers namely: population growth and dispersion, industrial growth and relocation of industrial activities, development and densification of road infrastructure network, tertiarization of the city centre, the emergence of new residential centres and activities related to a services and planning framework (Serra et al. 2008; Romano and Zullo 2013; Teixeira et al. 2014; Pinhal 2016; Barros et al. 2018). These dynamics allow one to relate the dynamics of LULC with the increase in the number of occurrences of hydro-geomorphologic origin.

\subsection{Relation with precipitation records}

A monthly mean precipitation analysis was also performed for the three periods analysed (Fig. 12), based on the Leiria meteorological station located in the study area. It should be noted that $78 \%$ of the hydro-geomorphological occurrences for the period 1958-2018 appear between the months of September and December. Between January and June the mean values of precipitation are higher in the period 1958-1984, with a tendency reversal between the months of July and October, that highlight the period 1985-1994 (Fig. 12). Between the months of November and December the average monthly precipitation returns to be higher for the period 1958-1984. The analysis of Figs. 11 and 12 shows that there is no direct relationship between the increase in impacts between 1995 and 2018 with the average monthly precipitation for the same period. In fact, comparing the average monthly precipitation between September and December, the period 1995-2018 presents a lower average with $86.3 \mathrm{~mm}$, whilst the period 1984-1995 has $95.6 \mathrm{~mm}$ and the period 1958-1984 has $94.2 \mathrm{~mm}$. This fact highlights what was mentioned above, namely on the

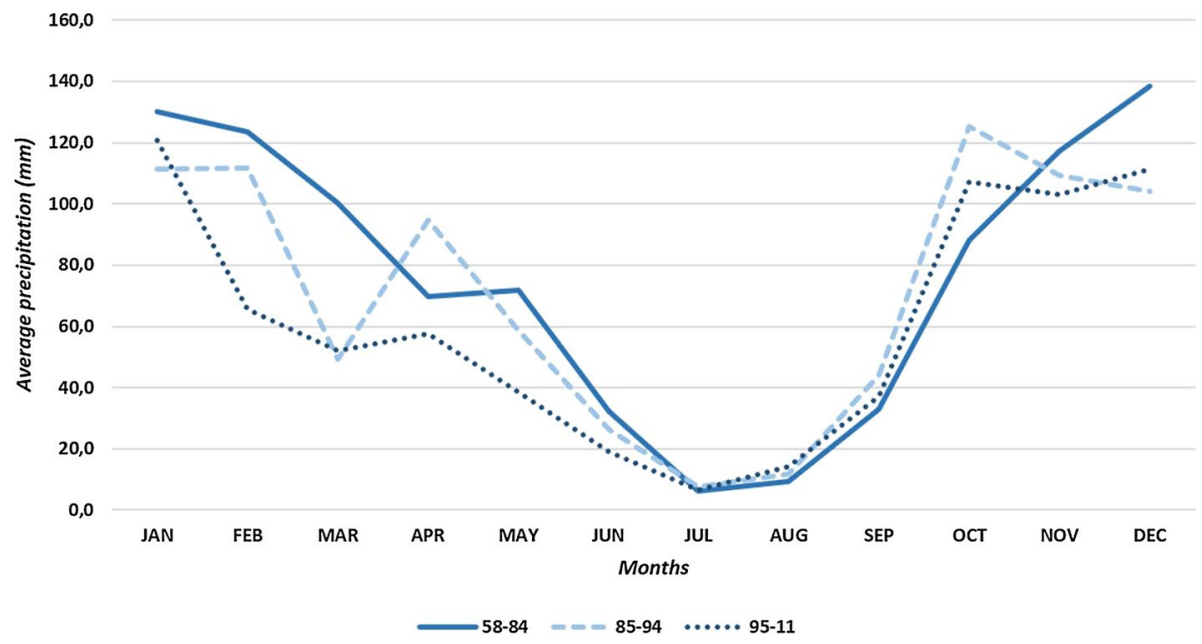

Fig. 12 Average monthly precipitation for the three analysed periods 
relationship between the dynamics of LULC and the increase in the number of hydro-geomorphologic occurrences.

\subsection{Cluster analysis: the relation between land use and land cover change and the hydro-geomorphologic occurrences}

The evaluation of the relation between the aggregated land use classes and the different impacts was processed using a hierarchical cluster analysis. From the 3 cluster solutions tested (with 2, 3 and 4 clusters) the grouping in clusters 2 and 3 is the one providing a basis for the more significant interpretations (Fig. 13). The results obtained using cluster analysis allow reinforcement of the previously mentioned findings.

From the outset, it can be observed that cluster 1 groups the variables expressing the artificial areas and the material losses. This fact is evidenced by the results obtained in the present work where we can verify that the great majority of occurrences with exclusively material losses occurred in artificial areas (73\%), followed by agricultural areas (19\%) and forest areas (8\%). Cluster 3 associates occurrences with human losses with forest areas. It is interesting that this later variable-which represents only $6 \%$ of the total of occurrences - is not associated with artificialized areas, meaning that the most serious consequences, like the loss of life, have been occurring outside of the urban context. In fact, occurrences with human losses do not seem to have a direct relationship with the processes of artificialization. Its systematic appearance in Sects. 2 and 3 seems to identify that there is a relationship with other forcers, such as extreme meteorological conditions associated with episodes of high precipitation, leading to a large number of evacuees in areas still with high agricultural occupation. Finally, cluster 2 is only represented by agricultural areas. However, when the number of clusters is reduced to 2, this once solitary variable prefers to group with forest areas and occurrences with human consequences and not with material consequences (cf. the dendrogram and the inserted table in Fig. 13).

In fact, it should also be noted that occurrences with human losses are located exclusively in Sects. 2 and 3, outside of the city centre. In the periods of 1958-1984 and 1985-1994 the disasters with human consequences occurred predominantly in agricultural areas, while in the period 1995-2018 they occurred predominantly in the recently artificialized areas. The analysis of LULC carried out highlights that agricultural and forest areas are related with the transformations of use and occupation between both, highlighting the

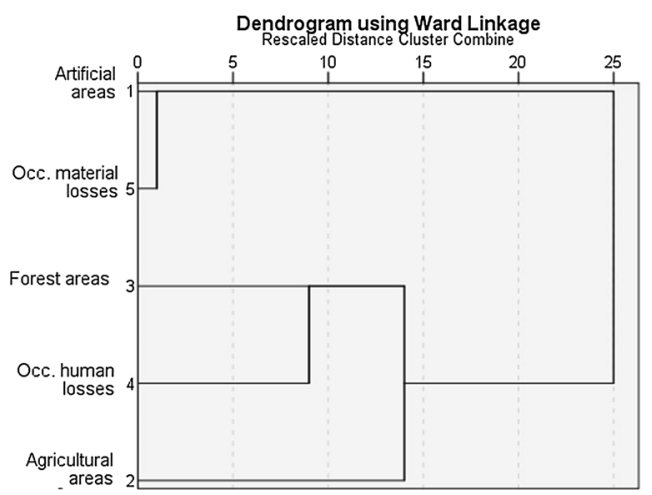

\begin{tabular}{|c|c|c|c|c|c|c|}
\hline \multicolumn{7}{|c|}{ Agglomeration Schedule } \\
\hline \multirow{2}{*}{ Stage } & \multicolumn{2}{|c|}{ Cluster Combined } & \multirow{2}{*}{ - Coefficients } & \multicolumn{2}{|c|}{$\begin{array}{c}\text { Stage Cluster First } \\
\text { Appears } \\
\end{array}$} & \multirow{2}{*}{$\begin{array}{l}\text { Next } \\
\text { Stage }\end{array}$} \\
\hline & Cluster 1 & Cluster 2 & & Cluster 1 & Cluster 2 & \\
\hline 1 & 1 & 5 & 2.756 & 0 & 0 & 4 \\
\hline 2 & 3 & 4 & 16.522 & 0 & 0 & 3 \\
\hline 3 & 2 & 3 & 35.329 & 0 & 2 & 4 \\
\hline 4 & 1 & 2 & 68.778 & 1 & 3 & 0 \\
\hline \multicolumn{7}{|c|}{ Cluster Membership } \\
\hline & Variable & & 4 Clusters & 3 Cluster & & Clusters \\
\hline & rtificial areas & & 1 & 1 & & 1 \\
\hline & ricultural area & & 2 & 2 & & 2 \\
\hline & orest areas & & 3 & 3 & & 2 \\
\hline Occ & human loss & & 4 & 3 & & 2 \\
\hline Occ & Material loss & & 1 & 1 & & 1 \\
\hline
\end{tabular}

Fig. 13 Cluster analysis dendrogram displaying three clusters association 
change from agricultural to forest areas, due to the abandonment of the prior activity. The identified clustering and temporal dynamics may indicate that urban expansion-replacing agricultural and forest areas-is being made to once non-artificialized areas, prone to be affected by hydro-geomorphological-related events.

\subsection{Implications related to spatial planning}

The results obtained in the present work allow the identification of urbanization and agroforestry dynamics as the main drivers of land use change. According to Barros et al. (2018) for Leiria the planning framework acts as an activator of land-use transformation processes. In fact, until the 1980s, the approval of a set of city-centred plans had been leading to an increase in landscape fragmentation and a consequent increase in soil artificialization processes. This dynamic is based on the search for new areas related to the emergence of new activities related to housing, services, industry and commerce. Thus, two areas of urban expansion were developed: to the north related to the development of housing centres linked to industry and services, and another to the south related to the development of low-density landscapes linked with typologies of isolated construction. Beginning in 1993, the application of the restrictions resulting from REN and RAN, and the Municipal Master Plan coming into force in 1995, led to greater regulation of the municipal space, resulting in limitations to the disorderly and diffuse urban expansion that existed until then (Barros et al. 2018).

The conversion of natural and agricultural to urban areas causes diverse negative impacts, with particular emphasis on peri-urban areas (Lauf et al. 2016; Russo et al. 2017). These negative impacts are manifested in various dimensions, including landscape fragmentation, loss of biodiversity, decreased environmental quality, increased exposure to risk due to the occupation of risk areas, changes in natural dynamics, particularly in regard to soil sealing, slope instability and anthropogenic occupation of floodplains (Hajdu et al. 2016; Mottaghi et al. 2016; Sallustio et al. 2017; Salvati et al. 2018; Barros et al. 2018).

The analysis allows us to identify the main land use dynamics between the last six decades for the city of Leiria, as well as to relate these dynamics with the historical records of hydro-geomorphological-related losses. The results show a constant increase in the soil artificialization and a sharp decrease in the natural and non-sealed surfaces, with emphasis on the agricultural areas. This process, particularly intense in the peri-urban area of Leiria (Sects. 2 and 3), results in alteration of the landscape and its natural dynamics. These negative impacts arise through modifications in the hydrological cycle and flood regimes (Carlson 2004; Weng 2012) as well as the destruction and reduction of vegetation cover, and the construction in steep areas (Reichenbach et al. 2014; Persichillo et al. 2017; Gariano et al. 2018). Several recent studies have shown that the risk of flooding increases significantly with increasing soil artificialization (Prosdocimi et al. 2015; Miller and Hutchins 2017; Berndtsson et al. 2019). On the other hand, there are also several studies that relate the different dynamics of land use change to landslide occurrence (Reichenbach et al. 2014; Pisano et al. 2017; Persichillo et al. 2017; Gariano et al. 2018) identifying LULC as key drivers, including urbanization in hazardous areas, abandonment of rural and mountain areas, wrong agricultural and forest practices, irrigation, deforestation and afforestation, with a direct effect on the distribution and frequency of landslides.

The results of this study are aligned with the main conclusions of the studies mentioned above. It is, therefore, possible to observe that the peri-urban areas of the city of Leiria have faced a high degree of pressure derived from the process of soil artificialization, based 
on the transition from natural and agricultural to urban areas (Barros et al. 2018). This transition interface between urban and rural is therefore a dynamic and multifaceted territory that needs to be understood from a multidisciplinary perspective (Hernández-Guerrero et al. 2012; Tavares et al. 2012; Gonçalves et al. 2017). In this sense only an integrated and multidisciplinary analysis can contribute to a better knowledge and evaluation of periurban areas in their multidimensionality and consequently contribute to a more resistant and resilient urban fringe. In this sense, the knowledge of the dynamics of LULC and their relationship with the occurrence of disasters in general, and those with a hydro-geomorphological origin in particular, are of great importance. This is especially true as climate models show that change will determine an increase in intensity and frequency of severe rainfall extreme events and could produce more slope failures (Gariano and Guzzetti 2016; Alvioli et al. 2018). The present research can contribute to a more resistant and resilient urban fringe by providing the different local stakeholders this knowledge related to the dynamics of LULC over the last 60 years in the city of Leiria, as well as its relationship to the detailed history of hydro-geomorphological occurrences. The results obtained allow for a differentiated analysis of the territory, contributing to a better definition of objectives and priorities not only related to spatial planning but also to risk and civil protection, thus contributing for more aware and informed stakeholders and citizens.

\section{Conclusions}

The methodology used in the present work allowed the identification and comparison of the different dynamics of LULC in spatial and temporal terms, verify the differentiated evolution throughout the territory. The use of cluster analysis and multiple regression enabled us to understand the existing relationship between the LULC processes, namely those related to peri-urbanization, as well as the occurrence of hydro-geomorphologic disasters, namely floods and landslides. The applied methodology can be replicated in different small and medium sized cities, with distinctive peri-urbanization processes.

The analysis demonstrates that the dispersion of population, activities, infrastructures, and consequently the artificialization dynamics, leads to a dispersion of hydro-geomorphologic occurrences throughout the territory in the analysed period. The transformations of LULC with emphasis in the growth of artificial areas give rise to an increase of hydrogeomorphologic disasters in the peripheral areas relative to the city centre, a trend that was the opposite in the initial periods analysed, where agricultural and forestry areas were still dominant. The results also point out that there is a relationship between the number of occurrences and the spaces in which there is competition between artificial and agricultural occupation, namely in the inner urban area (Sect. 2) and suburban area (Sect. 3).

Regarding the hydro-geomorphologic occurrences, the results show a growth in their number between 1958 and 2018. In terms of impact, referring to exclusively material losses, over the three analysed periods, the damages associated with road infrastructures and buildings predominate. This can be explained by the increase in exposure related to urbanization and urban sprawl. It is also noteworthy that the impacts on road infrastructures and commercial buildings remain constant over the periods under analysis, regardless of the rate of artificialization or extreme weather conditions. On the other hand, it should be noted that the impacts on residential buildings arise mainly due to the intense artificialization that occurred until 1994, as well as the appearance of new urban equipment and industrial areas, this process being related to peri-urbanization. It is also important 
to highlight that in the period 1958-1984 occurrences with human losses only happen in peripheral areas, namely in the suburban area (Sect. 3) dominated by agricultural and forest areas. For the period 1995-2018, we observe that this typology of occurrence is located predominantly in the inner urban area (Sect. 2) with a strong dynamics of soil artificialization highlighting the area called Ponte das Mestras that has a long history of flood events.

The character of uncertainty, interdependence and complexity associated with periurbanization processes call for an analysis such as the one presented in this work. This study serves as a tool for the local authorities as well as for the different stakeholders for exploring the effects of urbanization and peri-urbanization and the consequent artificialization of the soil and the relation with hydro-geomorphologic occurrences and their associated impacts. This knowledge can contribute to design policies and sustainable planning that promotes the resilience and the sustainability of the urban and peri-urban areas.

Acknowledgements This work is funded by Portuguese funds through "Fundação para a Ciência e a Tecnologia" (FCT/MEC - Portuguese Foundation for Science and Technology), within the scope of MOSAIC.

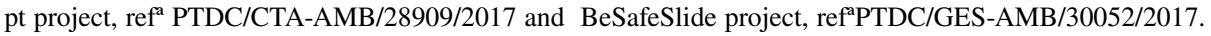
Pedro Pinto Santos was funded through FCT I.P., under the programme of 'Stimulus of Scientific Employment-Individual Support' within the contract CEECIND/00268/2017.

Code availability Not applicable.

\section{Compliance with ethical standards}

\section{Conflict of interest None.}

Availability of data and material Not applicable.

Open Access This article is licensed under a Creative Commons Attribution 4.0 International License, which permits use, sharing, adaptation, distribution and reproduction in any medium or format, as long as you give appropriate credit to the original author(s) and the source, provide a link to the Creative Commons licence, and indicate if changes were made. The images or other third party material in this article are included in the article's Creative Commons licence, unless indicated otherwise in a credit line to the material. If material is not included in the article's Creative Commons licence and your intended use is not permitted by statutory regulation or exceeds the permitted use, you will need to obtain permission directly from the copyright holder. To view a copy of this licence, visit http://creativecommons.org/licenses/by/4.0/.

\section{References}

Abrantes P, Fontes I, Gomes E, Rocha J (2016) Compliance of land cover changes with municipal land use planning: evidence from the Lisbon metropolitan region (1990-2007). Land Use Policy 51:120-134

Alcántara-Ayala I, Esteban-Chávez O, Parrot JF (2006) Landsliding related to land-cover change: a diachronic analysis of hillslope instability distribution in the Sierra Norte, Puebla, Mexico. CATENA 65(2):152-165. https://doi.org/10.1016/j.catena.2005.11.006

Alvioli M, Melillo M, Guzzetti F, Rossi M, Palazzi E, von Hardenberg J, Brunetti MT, Peruccacci S (2018) Implications of climate change on landslide hazard in Central Italy. Sci Total Environ 630:1528-1543. https://doi.org/10.1016/j.scitotenv.2018.02.315

Anderson MG, Holcombe E (2013) Community-based landslide risk reduction: managing disasters in small steps. World Bank Publications, Washington DC

Andrada E (1982) 80 anos de Actividade na Correcção Torrencial-Hidráulica Florestal (1901-1980), Ministério da Agricultura, Comércio e Pescas-Direcção Geral das Florestas, Lisboa

Barros JL, Tavares AO, Monteiro M, Santos PP (2018) Peri-urbanization and rurbanization in Leiria City: the importance of a planning framework. Sustainability 10(7):2501. https://doi.org/10.3390/su100 72501 
Beniston M, Stephenson DB, Christensen OB, Ferro CAT, Frei C, Goyette S, Halsnaes K, Holt T, Jylha K, Koffi B, Palutikof J, Scholl R, Semmler T, Woth K (2007) Future extreme events in European climate: an exploration of regional climate model projections. Clim Change 81(1):71-95. https:// doi.org/10.1007/s10584-006-9226-Z

Berndtsson R, Becker P, Persson A, Aspegren H, Haghighatafshar S, Jonsson K, Larsson R, Mobini S, Mottaghi M, Nilsson J, Nordstrom J, Pilesjo P, Scholz M, Sternudd C, Sorensen J, Tussupova K (2019) Drivers of changing urban flood risk: a framework for action. J Environ Manag 240:47-56

Bodesmo N, Pacicco L, Romano B, Ranfa A (2012) The role of environmental and socio-demographic indicators in the analysis of land use changes in a protected area of the Natura 2000 Network: the case study of Lake Trasimeno, Umbria, Central Italy. Environ Monit Assess 184:831-843. https:// doi.org/10.1007/s10661-011-2004-z

Bossard M, Feranec J, Otahel J (2000) Corine land cover technical guide-Addendum. Technical Report No 40. EEA, Copenhagen

Bruschi VM, Bonachea J, Remondo J, Gomez-Arozamena J, Rivas V, Barbieri M, Capocchi S, Soldati M, Cendrero A (2013) Land management versus natural factors in land instability: some examples in northern Spain. Environ Manag 52(2):398-416. https://doi.org/10.1007/s00267-013-0108-7

Buhaug H, Urdal H (2013) An urbanization bomb? Population growth and social disorder in cities. Glob Environ Change 23(1):1-10. https://doi.org/10.1016/j.gloenvcha.2012.10.016

Carisi F, Domeneghetti A, Castellarin A (2016) Effects of anthropogenic land-subsidence on inundation dynamics: the case study of Ravenna, Italy. Proc Int As Hydrol Sci 373:161-166. https://doi. org/10.5194/piahs-373-161-2016

Carlson TN (2004) Analysis and prediction of surface runoff in an urbanizing watershed using satellite imagery. J Am Water Resour As 40(4):1087-1098. https://doi.org/10.1111/j.1752-1688.2004.tb010 69. $\mathrm{x}$

Cavaco C, Vilares E, Rosa F, Magalhães M, Esteves N, Tavares M (2015) Cidades Sustentáveis 2020. Direção-Geral do Território, Lisboa

Chadchan J, Shankar R (2012) An analysis of urban growth trends in the post-economic reforms period in India. Int J Sustain Built Environ 1(1):36-49. https://doi.org/10.1016/j.ijsbe.2012.05.001

Crozier MJ (2010) Deciphering the effect of climate change on landslide activity: a review. Geomorphology 124:260-267. https://doi.org/10.1016/j.geomorph.2010.04.009

Duràn F (2006) Difusión Urbana y Cambio Social en los Territorios Rurales: un estudio de casos en la provincia de Granada. Revista de Estudios Regionales 3:179-203

EEA (1990) Corine Land Cover (CLC1990) 100 m-version 12/2000. European Environment Agency. http://www.eea.europa.eu/data-and-maps/data. Accessed 10 Jan 2020

EEA (2006) Urban Sprawl in Europe-The ignored challenge. European Environment Agency, Copenhagen

Fertner C, Jørgensen G, Nielsen TAS, Nilsson KSB (2016) Urban sprawl and growth management-drivers, impacts and responses in selected European and US cities. Future Cities Environ 2(1):9. https:// doi.org/10.1186/s40984-016-0022-2

Field CB, Barros V, Stocker TF, Dahe Q (2012) Managing the risks of extreme events and disasters to advance climate change adaptation: special report of the intergovernmental panel on climate change. Cambridge University Press, Cambridge

Freire S, Santos T, Tenedório J (2009) Recent urbanization and land use/land cover change in Portugalthe influence of coastline and coastal urban centers. J Coast Res 56:1499-1503

Gallent N, Andersson J, Bianconi M (2006) Planning on the edge: the context for planning at the ruralurban fringe. Routledge, Abingdon

Gariano SL, Guzzetti F (2016) Landslides in a changing climate. Earth Sci Rev 162:227-252. https:// doi.org/10.1016/j.earscirev.2016.08.011

Gariano SL, Petrucci O, Rianna G, Santini M, Guzzetti F (2018) Impacts of past and future land changes on landslides in southern Italy. Reg Environ Change 18(2):437-449. https://doi.org/10.1007/s1011 3-017-1210-9

Gaspar J (2005) Cidade e urbanização no virar do milénio. Libro de Homenaje a Joaquín González Vecín, Departamento de Geografia, Universidad de León, pp 285-299

Glade T (2003) Landslide occurrence as a response to land use change: a review of evidence from New Zealand. CATENA 51:297-314. https://doi.org/10.1016/s0341-8162(02)00170-4

Gonçalves J, Gomes MC, Ezequiel S, Moreira F, Loupa-Ramos I (2017) Differentiating peri-urban areas: a transdisciplinary approach towards a typology. Land Use Policy 63:331-341. https://doi. org/10.1016/j.landusepol.2017.01.041

Guerra AJT, Fullen MA, Jorge MCO, Bezerra JFR, Shokr MS (2017) Slope processes, mass movement and soil erosion: a review. Pedosphere 27:27-41. https://doi.org/10.1016/S1002-0160(17)60294-7 
Hajdu F, Penje O, Fischer K (2016) Questioning the use of 'degradation' in climate mitigation: a case study of a forest carbon CDM project in Uganda. Land Use Policy 59:412-422. https://doi.org/10.1016/j. landusepol.2016.09.016

Hennig EI, Schwick C, Soukup T, Orlitová E, Kienast F, Jaeger JA (2015) Multi-scale analysis of urban sprawl in Europe: towards a European de-sprawling strategy. Land Use Policy 49:483-498. https://doi. org/10.1016/j.landusepol.2015.08.001

Hernández-Guerrero J, Vieyra-Medrano A, Mendoza ME (2012) Adaptation strategies in communities under precarious housing: flooding risks in the peri-urban sector of the city of Morelia Michoacán, México. Appl Geogr 34:669-679. https://doi.org/10.1016/j.apgeog.2012.04.010

INE (2004) Sistema urbano: Áreas de influência e marginalidade funcional. Região Centro. National Institute of Statistics, Lisbon

INE (2012) Censos 2011 Resultados Definitivos e Portugal. National Institute of Statistics, Lisbon

Jacinto R (2009) As cheias na cidade de Leiria: Contributo dos SIG para o ordenamento do território. Dissertação de mestrado, Faculdade de Letras da Universidade do Porto, Porto

Jones N, de Graaff J, Rodrigo I, Duarte F (2011) Historical review of land use changes in Portugal (before and after EU integration in 1986) and their implications for land degradation and conservation, with a focus on Centro and Alentejo regions. Appl Geogr 31:1036-1048. https://doi.org/10.1016/j.apgeo g.2011.01.024

Lambin EF, Geist HJ (eds) (2008) Land-use and land-cover change: local processes and global impacts. Springer, Berlin

Lauf S, Haase D, Kleinschmit B (2016) The effects of growth, shrinkage, population aging and preference shifts on urban development-a spatial scenario analysis of Berlin, Germany. Land Use Policy 52:240-254. https://doi.org/10.1016/j.landusepol.2015.12.017

Leontidou L, Couch C (2007) Urban sprawl and hybrid city-scapes in Europe: comparisons, theory construction and conclusions. In: Couch C, Leontidou L, Petschel-Held G (eds) Urban sprawl in Europe: landscapes, land-use change and policy. Wiley, Oxford

Li Z, Liu WZ, Zhang XC, Zheng FL (2009) Impacts of land use change and climate variability on hydrology in an agricultural catchment on the Loess Plateau of China. J Hydrol 377:35-42. https://doi. org/10.1016/j.jhydrol.2009.08.007

Li X, Zhou W, Ouyang Z (2013) Forty years of urban expansion in Beijing: What is the relative importance of physical, socioeconomic, and neighborhood factors? Appl Geogr 38:1-10. https://doi.org/10.1016/j. apgeog.2012.11.004

Loibl W, Toetzer T (2003) Modelling growth and densification processes in sub-urban regions simulation of landscape transition with spatial agents. Environ Modell Softw 18:553-563. https://doi.org/10.1016/ S1364-8152(03)00030-6

Long H, Tang G, Li X, Heilig GK (2007) Socio-economic driving forces of land-use change in Kunshan, the Yangtze River Delta economic area of China. J Environ Manag 83:351-364. https://doi.org/10.1016/j. jenvman.2006.04.003

Mantas VM, Marques JC, Pereira AJ (2016) A geospatial approach to monitoring impervious surfaces in watersheds using Landsat data (the Mondego Basin, Portugal as a case study). Ecol Ind 71:449-466. https://doi.org/10.1016/j.ecolind.2016.07.013

Marôco J (2014) Análise Estatística com o SPSS Statistics.: $7^{a}$ edição. Report Number, Lda, Pêro Pinheiro

Masini E, Tomao A, Barbati A, Corona P, Serra P, Salvati L (2019) Urban growth, land-use efficiency and local socioeconomic context: a comparative analysis of 417 metropolitan regions in Europe. Environ Manag 63(3):322-337. https://doi.org/10.1007/s00267-018-1119-1

Meneses BM, Reis E, Vale MJ, Reis R (2018) Modelling the land use and land cover changes in Portugal: a multi-scale and multi-temporal approach. Finisterra 53(107):3-26

Meusburger K, Alewell C (2008) Impacts of anthropogenic and environmental factors on the occurrence of shallow landslides in an alpine catchment (Urseren Valley, Switzerland). Nat Hazards Earth Syst Sci 8:509-520. https://doi.org/10.5194/nhess-8-509-2008

Miceli R, Sotgiu I, Settanni M (2008) Disaster preparedness and perception of flood risk: a study in an alpine valley in Italy. J Environ Psychol 28(2):164-173. https://doi.org/10.1016/j.jenvp.2007.10.006

Miller JD, Hutchins M (2017) The impacts of urbanisation and climate change on urban flooding and urban water quality: a review of the evidence concerning the United Kingdom. J Hydrol Reg Stud 12:345362. https://doi.org/10.1016/j.ejrh.2017.06.006

Monteiro M, Tavares A (2015) What is the influence of the planning framework on the land use change trajectories? Photointerpretation analysis in the 1958-2011 Period for a Medium/Small Sized City. Sustainability. https://doi.org/10.3390/su70911727 
Mottaghi M, Aspegren H, Jönsson K (2016) Integrated urban design and open storm drainage in our urban environments: merging drainage techniques into our city's urban spaces. Water Pract Technol J 11:118-126. https://doi.org/10.2166/wpt.2016.016

Napolitano E, Marchesini I, Salvati P, Donnini M, Bianchi C, Guzzetti F (2018) LAND-deFeND-An innovative database structure for landslides and floods and their consequences. J Environ Manag 207:203-218. https://doi.org/10.1016/j.jenvman.2017.11.022

Nijkamp P, Perrels A (2018) Sustainable cities in Europe. Routledge, London

Nilsson K, Pauleit S, Bell S, Aalbers C, Nielsen TAS (eds) (2013) Peri-urban futures: Scenarios and models for land use change in Europe. Springer, Berlin

Onishi T, Khan T, Hiramatsu K (2014) Impact of land-use change on flooding patterns. In: Dhaka megacity. Springer, Netherlands, Dordrecht, pp 163-175. https://doi.org/10.1007/978-94-007-6735-5_9

Papathoma-Köhle M, Glade T (2013) The role of vegetation cover change for landslide hazard and risk. In: Renaud F, Sudmeier- Rieux K, Estrella M (eds) The role of ecosystems in disaster risk reduction. UNU-Press, Tokyo, pp 293-320

Parise M, Vennari C (2013) A chronological catalogue of sinkholes in Italy: the first step toward a real evaluation of the sinkhole hazard. In: Proceeding of 13th multidisciplinary conference on sinkholes and the engineering and environmental impacts of Karst, at Carlsbad, New Mexico (USA), 2013, pp 383-392. ISBN 978-0-9795422-7-5

Parise M, Vennari C (2017) Distribution and features of natural and anthropogenic sinkholes in Apulia. In: Renard P, Bertrand C (eds) EuroKarst 2016, Neuchatel. Advances in the hydrogeology of karst and carbonate reservoirs, pp 27-34. Springer. ISBN 978-3-319-45464-1

Pattison I, Lane SN (2012) The link between land-use management and fluvial flood risk: a chaotic conception? Prog Phys Geogr 36(1):72-92. https://doi.org/10.1177/0309133311425398

Pedrosa P (2006) A integração da prevenção dos riscos no ordenamento territorial. Colóquio sobre Paisagens, Património e Riscos Naturais: Perspectivas de Planeamento Comparado. Coimbra

Persichillo MG, Bordoni M, Meisina C (2017) The role of land use changes in the distribution of shallow landslides. Sci Total Environ 574:924-937. https://doi.org/10.1016/j.scitotenv.2016.09.125

Pinhal AFP (2016) Território da Urbanização Extensiva: Processos, Lógicas e Formas de Transformação Urbana em Leiria. PhD Thesis. Porto University, Porto

Piorr A (ed) (2011) Peri-urbanisation in Europe: towards European policies to sustain urban-rural futures; synthesis report, PLUREL [sixth framework programme]. Forest and Landscape, University of Copenhagen

Pisano L, Zumpano V, Malek Z, Rosskopf CM, Parise M (2017) Variations in the susceptibility to landslides, as a consequence of land cover changes: a look to the past, and another towards the future. Sci Total Environ. https://doi.org/10.1016/j.scitotenv.2017.05.231

Portuguese Territory's General Directorate (2019) Especificações técnicas da Carta de Uso e Ocupação do Solo (COS) de Portugal Continental para 2018. Relatório Técnico. Direção-Geral do Território

Prosdocimi I, Kjeldsen TR, Miller JD (2015) Detection and attribution of urbanization effect on flood extremes using nonstationary flood-frequency models. Water Resour Res 51:4244-4262. https:// doi.org/10.1002/2015WR017065

Ravetz J, Fertner C, Nielsen TS (2013) The dynamics of peri-urbanization. In: Peri-urban futures: scenarios and models for land use change in Europe, pp 13-44. Springer, Berlin

Reichenbach P, Mondini AC, Rossi M (2014) The influence of land use change on landslide susceptibility zonation: the Briga catchment test site (Messina, Italy). Environ Manag 54(6):1372-1384. https ://doi.org/10.1007/s00267-014-0357-0

Rojas RV (2002) Fragmentation de la ville et noveaux modes de composition urbaine. Collection Villes et Entreprises, L'Harmattan, France

Romano B, Zullo F (2013) Models of urban land use in Europe: assessment tools and criticalities. Int J Agric Environ Inf Syst 4(3):80-97. https://doi.org/10.4018/ijaeis.2013070105

Russo AP, Serrano Giné D, Pérez Albert MY, Brandajs F (2017) Identifying and classifying small and medium sized towns in Europe. Tijdschr Econ Soc Geogr. https://doi.org/10.1111/tesg.12251

Salgueiro TB (2006) Oportunidade e transformação na cidade centro. Finisterra 41(81):9-32

Sallustio L, De Toni A, Strollo A, Febbraro M, Gissi E, Casella L, Geneletti D, Munafò M, Vizzarri M, Marchetti M (2017) Assessing habitat quality in relation to the spatial distribution of protected areas in Italy. J Environ Manag 201:129-137. https://doi.org/10.1016/j.jenvman.2017.06.031

Salvati L, Zambon I, Chelli FM, Serra P (2018) Do spatial patterns of urbanization and land consumption reflect different socioeconomic contexts in Europe? Sci Total Environ 625:722-730. https:// doi.org/10.1016/j.scitotenv.2017.12.341 
Schneidewind P (2006) The Role of Small and Medium-Sized Towns (SMESTO), Final Report, ESPON 1.4. 1. Österreichisches Institut für Raumplanung (ÖIR)_Austrian Institute for Regional Studies and Spatial Planning, Viena

Seneviratne SI, Nicholls N, Easterling D, Goodess CM, Kanae S, Kossin J, Luo Y, Marengo J, McInnes K, Rahimi M, Reichstein M, Sorteberg A, Vera C, Zhang X (2012) Changes in climate extremes and their impacts on the natural physical environment. In: Field CB, Barros V, Stocker TF, Qin D, Dokken DJ, Ebi KL, Mastrandrea MD, Mach KJ, Plattner G-K, Allen SK, Tignor M, Midgley PM (eds) Managing the risks of extreme events and disasters to advance climate change adaptation: a special report of working groups I and II of the Intergovernmental Panel on Climate Change (IPCC). Cambridge University Press, Cambridge, pp 109-230

Serra P, Pons X, Saurí D (2008) Land-cover and land-use change in a Mediterranean landscape: a spatial analysis of driving forces integrating biophysical and human factors. Appl Geogr 28(3):189-209. https ://doi.org/10.1016/j.apgeog.2008.02.001

Sherestha M, York A, Boone C, Zhang S (2011) Land fragmentation due to rapid urbanization in the Phoenix metropolitan area: analyzing the spatio- temporal patterns and drivers. Appl Geogr 31:522-531. https://doi.org/10.1016/j.apgeog.2011.04.004

Skokanová H, Havlíček M, Borovec R (2012) Development of land use and main land use change processes in the period 1836-2006: case study in the Czech Republic. J Maps 8:88-96. https://doi. org/10.1080/17445647.2012.668768

Sofia G, Roder G, Dalla Fontana G, Tarolli P (2017) Flood dynamics in urbanised landscapes: 100 years of climate and humans' interaction. Sci Rep 7:40527. https://doi.org/10.1038/srep40527

Tavares A, Pato R, Magalhães M (2012) Spatial and temporal land use change and occupation over the last half century in a peri-urban area. Appl Geogr 34:432-444. https://doi.org/10.1016/j.apgeo g.2012.01.009

Tavares A, Monteiro M, Vargas M, Pato R, Serra R (2014) Land use change and forest routing in a rural context: the relevance of the community-based management and planning framework. Appl Geogr 52:153-171. https://doi.org/10.1016/j.apgeog.2014.05.008

Teixeira C, Zbyszewski G (1968) Geological Map of Portugal at scale 1/50 000. Explanatory notice of 23-C sheet (Leiria). Lisbon: Geological Services of Portugal

Teixeira Z, Teixeira H, Marques JC (2014) Systematic processes of land use/land cover change to identify relevant driving forces: implications on water quality. Sci Total Environ 470:1320-1335. https://doi. org/10.1016/j.scitotenv.2013.10.098

Trenberth KE (2011) Changes in precipitation with climate change. Clim Res 47(1-2):123-138

United Nations (2017) Department of Economic and Social Affairs, Population Division 2017. World Population Prospects: The 2017 Revision, Key Findings and Advance Tables. Working Paper No.ESA/P/ WP/248. https://esa.un.org/unpd/wpp/publications/files/wpp2017_keyfindings.df

Van Den Eeckhaut M, Poesen J, Van Gils M, Van Rompaey A, Vandekerckhove L (2009) How do humans interact with their environment in residential areas prone to landsliding? A case study from the Flemish Ardennes. In: Proceedings of the international conference on "landslide processes: from geomorphologic mapping to dynamic modelling," Strasbourg, France, 6-7 February 2009, pp 19-24

Veiga A (2011) Geotechnical characterization of the terraines of Parceiros-Leiria typhonic valley. PhD Thesis. Coimbra University, Coimbra

Vitagliano E, Riccardi U, Piegari E, Boy JP, Di Maio R (2020) Multi-component and multi-source approach for studying land subsidence in deltas. Remote Sens 12(9):1465

Weng Q (2012) Remote sensing of impervious surfaces in the urban areas: requirements, methods, and trends. Remote Sens Environ 117:34-49. https://doi.org/10.1016/j.rse.2011.02.030

Zêzere JL, Pereira S, Tavares AO, Bateira C, Trigo RM, Quaresma I, Santos PP, Santos M, Verde J (2014) DISASTER: a GIS database on hydro-geomorphologic disasters in Portugal. Nat Hazards 72(2):503532. https://doi.org/10.1007/s11069-013-1018-y

Zhang Y, Xia J, Yu J, Randall M, Zhang Y, Zhao T, Pan X, Zhai X, Shao Q (2018) Simulation and assessment of urbanization impacts on runoff metrics: insights from landuse changes. J Hydrol 560:247-258. https://doi.org/10.1016/j.jhydrol.2018.03.031

Publisher's Note Springer Nature remains neutral with regard to jurisdictional claims in published maps and institutional affiliations. 